\title{
Residual Risk Reduction Initiative: výzva ke snížení reziduálního vaskulárního rizika u pacientů s dyslipidemií
}

\author{
Jean-Charles Fruchart, Frank M. Sacks, Michel P. Hermans, Gerd Assmann, W. Virgil Brown, Richard Ceska, \\ M. John Chapman, Paul M. Dodson, Paola Fioretto, Henry N. Ginsberg, Takashi Kadowaki, Jean-Marc \\ Lablanche, Nikolaus Marx, Jorge Plutzky, Zeljko Reiner, Robert S. Rosenson, Bart Staels, Jane K. Stock, \\ Rody Sy, Christoph Wanner, Alberto Zambon, Paul Zimmet
}

Souhrnný přehled Residual Risk Reduction Initiative, $\mathrm{R}^{3} \mathrm{i}^{*}$

Navzdory současným standardům léčby zaměřené na dosažení cílových hodnot LDL cholesterolu, krevního tlaku a glykemie mají pacienti s dyslipidemií vysoké reziduální riziko vzniku vaskulárních příhod. Aterogenní dyslipidemie, zejména vyšší hodnota triglyceridů a nízká koncentrace HDL cholesterolu, se často vyskytuje spolu s vyšší koncentrací apolipoproteinu B a non-HDL cholesterolu u pacientů s diagnostikovanými kardiovaskulárními onemocněními, diabetes mellitus 2. typu, obezitou nebo metabolickým syndromem a je spojena s reziduálním makrovaskulárním a mikrovaskulárním rizikem. Residual Risk Reduction Initiative ( $\left.\mathrm{R}^{3} \mathrm{i}\right)$ byla založena proto, aby se touto důležitou problematikou zabývala.

Cílem tohoto souhrnného přehledu je vyzdvihnout skutečnost, že se aterogenní dyslipidemie podílí na reziduálním makrovaskulárním riziku a mikrovaskulárních komplikacích, a doporučit léčebnou intervenci vedoucí ke snížení tohoto rizika, podpořenou důkazy a odborným konsensem. Důležitým prvním krokem je úprava životního stylu. Často je mimo to nutná také farmakoterapie. Přidání niacinu, fibrátu nebo $\omega$-3 mastných kyselin k terapii statiny zlepšuje všechny lipidové rizikové faktory. Klinické studie hodnotí, zda mají tyto strategie lepší klinický přínos než léčba statiny. Závěrem Ize říci, že iniciativa $R^{3} i$ zdůrazňuje potřebu ovlivnit vysokou míru reziduálního vaskulárního rizika u pacientů s dyslipidemií, kteří jsou léčeni prostřednictvím úpravy životního stylu anebo farmakoterapií v souladu se současnými standardy léčby.

Diabetes Vasc Dis Res 2008;5:319-335.

Klíčová slova: Životní styl - Makrovaskulární komplikace - Mikrovaskulární komplikace - Farmakoterapie - Reziduální riziko

* Residual Risk Reduction Initiative ( $\left.\mathrm{R}^{3} \mathrm{i}\right)$ je nezávislou, neziskovou vzdělávací organizací, která sdružuje vědce provádějící základní a klinický výzkum, kardiology, endokrinology a diabetology a jež vznikla, aby se věnovala této problematice. Je registrována ve Švýcarsku podle jeho právního systému tak, aby bylo zajištěno vědecké vedení a kontrola nad aktivitami iniciativy. $V$ současnosti tuto iniciativu podporuje společnost Solvay Pharmaceuticals.

\section{Základní informace: definice problému}

Úspěchy, jichž bylo za poslední čtyři desetiletí dosaženo v prevenci kardiovaskulárních onemocnění, jsou nyní vážně ohrožovány dopadem globální epidemie obezity, metabolického syndromu a diabetes mellitus 2 . typu. ${ }^{1}$ Podle nejnovějších údajů existuje dokonce možnost obratu v mortalitě na srdeční onemocnění, zejména u mladších mužů a žen. 2,3 Tento vývoj bude mít nepochybně vliv na náklady na léčbu kardiovaskulárních onemocnění, které se v současné době odhadují přibližně na 450 miliard USD ročně v USA ${ }^{4}$ a 300 miliard USD v Evropè. ${ }^{5}$

Současné standardy prevence kardiovaskulárních onemocnění zdůrazňují důležitost multifaktoriální intervence vedoucí $\mathrm{k}$ dosažení doporučených cílových hodnot LDL (low density lipoprotein) cholesterolu, krevního tlaku a glykemie. ${ }^{6-11}$ Diabetes mellitus 2 . typu je také spojen s vyšším rizikem vzniku kardiovaskulárních onemocnění. ${ }^{6}$ Avšak jak ukázala klinická studie STENO-2, multifaktoriální intervence není až u poloviny diabetiků 2. typu dostatečná pro prevenci vzniku nebo progrese mikrovaskulárních komplikací (obrázek 1).12,13 Ačkoli je léčba statiny základním kamenem léčby dyslipidemie, což dokládají i výsledky velkých prospektivních klinických studií, významné riziko kardiovaskulárních onemocnění přetrvává navzdory účinné léčbě snižující koncentraci LDL cholesterolu. Údaje z nedávno provedené metaanalýzy, která zahrnovala 90056 pacientů (18 686 diabetiků) ve 14 randomizovaných klinických studiích, prokázaly, že v průběhu pěti let došlo k výskytu vaskulární příhody u jednoho ze sedmi léčených pacientů. ${ }^{14,15}$ Toto reziduální riziko zcela neodstraní ani další snížení koncentrace LDL cholesterolu maximální dávkou statinů (obrázek 2). ${ }^{16,17}$ 


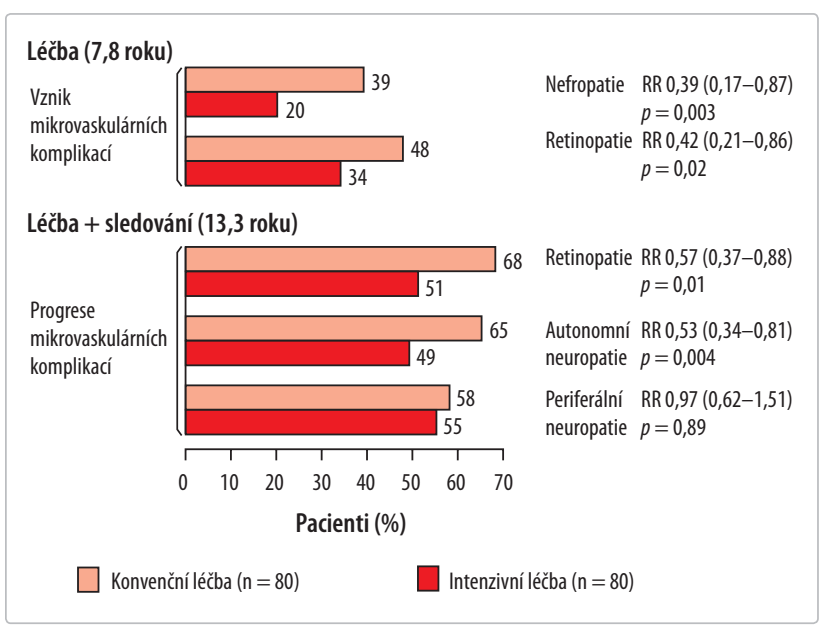

Obrázek 1 Intenzivní multifaktoriální intervence v klinické studii STENO-2 významně snížila vznik nebo progresi mikrovaskulárních komplikací souvisejících s diabetem, ale u mnoha pacientů těmto komplikacím nedokázala zabránit ${ }^{12,13}$

Diabetická nefropatie byla definována jako močová exkrece albuminu > 300 mg za 24 hodin ve dvou ze tří sterilních vzorků moči. Diabetická retinopatie byla hodnocena podle šestistupňové hodnoticí stupnice European Community-funded Concerted Action Programme into the Epidemiology and Prevention of Diabetes dvěma nezávislými oftalmology, kteří neznali přiřazení léčby. Periferní neuropatie byla stanovena pomocí biothesiometru. Autonomní neuropatie byla diagnostikována na základě měření RR intervalu na EKG v průběhu řízeného dýchání a testem ortostatické hypotenze provedeným laboratorním technikem, který neznal přiřazení léčby pacientům.

$\mathrm{RR}=$ relativní riziko $(95 \% \mathrm{Cl}=$ confidence interval, interval spolehlivosti)



Obrázek 2 Ve studii TNT ${ }^{16}$ přetrvávala vysoká úroveň reziduálního rizika výskytu závažných kardiovaskulárních příhod po snižení LDL cholesterolu pod úroveň současných cílových hodnot pomocí vysokých dávek atorvastatinu

Závažné kardiovaskulární príhody byly definovány jako kombinace úmrtí v důsledku ICHS, nefatálního neléčeného infarktu myokardu, resuscitace po srdeční zástavě a fatální nebo nefatální CMP.

HR - poměr rizik (hazard ratio), LDL - lipoproteiny o nízké hustotě, TNT - Treating to New Targets
Je zřejmé, že je nezbytné rychle zaměřit pozornost na účinné intervence vedoucí ke snížení reziduálního rizika kardiovaskulárních příhod a mikrovaskulárních komplikací u pacientů s dyslipidemií, kteří již jsou léčeni v souladu se současnými léčebnými standardy. Vedení léčby aterogenní dyslipidemie, se kterou se typicky setkáváme u pacientů s metabolickým syndromem, není zcela optimální a bude předmětem tohoto rozboru.

\section{Aterogenní dyslipidemie: běžný nález u pacientů s dyslipidemí}

Na reziduálním vaskulárním riziku se může podílet dyslipidemie, jak naznačila klinická studie INTERHEART, která prokázala, že dyslipidemie zodpovídá za více než 50 \% rizika infarktu myokardu v populaci. LDL cholesterol však není jediným lipoproteinem, který toto riziko určuje. ${ }^{18}$ Aterogenní dyslipidemie charakterizovaná zvýšenou koncentrací triglyceridů (TG) a nízkou plazmatickou koncentrací HDL cholesterolu se často vyskytuje spolu s vyšší koncentrací apolipoproteinu B a non-HDL cholesterolu u pacientů s diabetes mellitus 2. typu, metabolickým syndromem anebo diagnostikovanými kardiovaskulárními onemocněními (tabulka 1). ${ }^{19,20}$ Riziko spojené s aterogenní dyslipidemií s rizikem zvýšené koncentrace LDL cholesterolu nekoreluje, ale doplňuje ho.

\section{Aterogenní dyslipidemie a makrovaskulární riziko}

Značné množství důkazů ukazuje, že vyšší koncentrace triglyceridů a nízká koncentrace HDL cholesterolu jsou prediktory kardiovaskulárních onemocnění, a to nezávisle

Tabulka 1 Dyslipidemie související s diabetes mellitus 2. typu a metabolickým syndromem

Hlavní nezávislé* rizikové faktory KVO

- $\downarrow$ koncentrace HDL cholesterolu

- $\downarrow$ apolipoproteinu A-I

- $\uparrow$ TG a lipoproteinů bohatých na TG

- $\uparrow$ non-HDL cholesterolu

- $\uparrow$ apolipoproteinu B

Jiné související rizikové faktory ${ }^{\dagger}$

- $\uparrow$ postprandiálních TG

- $\uparrow$ počtu LDL částic (stanoveného pomocí MR)

- $\uparrow$ apolipoproteinu C-III

Jiné projevy dyslipidemie

- Malé denzní LDL

- Malé HDL, prebeta-1 HDL, alfa-3 HDL

HDL - lipoproteiny o vysoké hustotě (high-density lipoprotein), KVO - kardiovaskulární onemocnění, LDL - lipoproteiny o nízké hustotě (low-density lipoprotein), MR - magnetická rezonance, TG - triglyceridy

* Nezávislé na jiných hlavních lipidových a nelipidových rizikových faktorech prokázaných v mnoha velkých klinických studiích.

† Nezávislé na jiných hlavních lipidových a nelipidových rizikových faktorech, ale s méně obsáhlou databází. 
na LDL cholesterolu. ${ }^{21-23}$ Ještě větší význam pro stanovení kardiovaskulárního rizika mohou mít koncentrace TG změřené 2-4 hodiny po jídle, protože aterogenní remnanty lipoproteinů vylučované játry a střevem postprandiálně cirkulují ve vyšších koncentracích než nalačno, což prokazují klinické studie. ${ }^{24-25}$ Navíc, jak ukázala klinická studie Prospective Cardiovascular Münster (PROCAM), je pro stanovení kardiovaskulárního rizika nutné zvážit také poměr celkového cholesterolu a HDL cholesterolu. V klinické studii PROCAM byl zaznamenán infarkt myokardu u jednoho ze sedmi pacientů se současným výskytem vysokého poměru celkový/HDL cholesterol $(>5,0)$, nízké koncentrace HDL cholesterolu ( $<35 \mathrm{mg} / \mathrm{dl}, 0,90 \mathrm{mmol} / \mathrm{l})$ a vyšší koncentrace TG ( $\geq 200 \mathrm{mg} / \mathrm{dl}, 2,26 \mathrm{mmol} / \mathrm{l}){ }^{26}$

Zatímco jsou u pacientů s diabetem anebo metabolickým syndromem hodnoty LDL cholesterolu často normální nebo pouze mírně zvýšené, koncentrace apoB mohou být zvýšené. ${ }^{27}$ Koncentrace apoB představuje součet koncentrací aterogenních částic (very low-density lipoproteins [VLDL], intermediate-density lipoproteins [IDL], IDL remnanty, LDL a lipoprotein(a)), protože každá částice VLDL, IDL a LDL přenáší jednu molekulu apoB. Proto nepřekvapuje, že podle převážné části důkazů je koncentrace apoB lepším prediktorem rizika ischemické choroby srdeční (ICHS) než LDL cholesterol. ${ }^{28-35}$ Koncentrace ApoB (nebo LDL stanovená magnetickou rezonancí $[\mathrm{MR}]$ ) také významněji korelovala se zvyšujícím se počtem složek metabolického syndromu (obrázek 3). ${ }^{36}$ I když s metabolickým syndromem jsou spojeny spíše malé LDL částice s nižším obsahem cholesterolu, samotná malá velikost LDL částic nebyla prokázána jako nezávislý prediktor kardiovaskulárních onemocnění, kterými jsou mimo jiné TG, HDL cholesterol a apoB. ${ }^{37,38}$ Nedávno zveřejněná konsensuální doporučení ADA/ACC (American Diabetes Association/American College of Cardiology) pro vedení léčby dyslipoproteine-

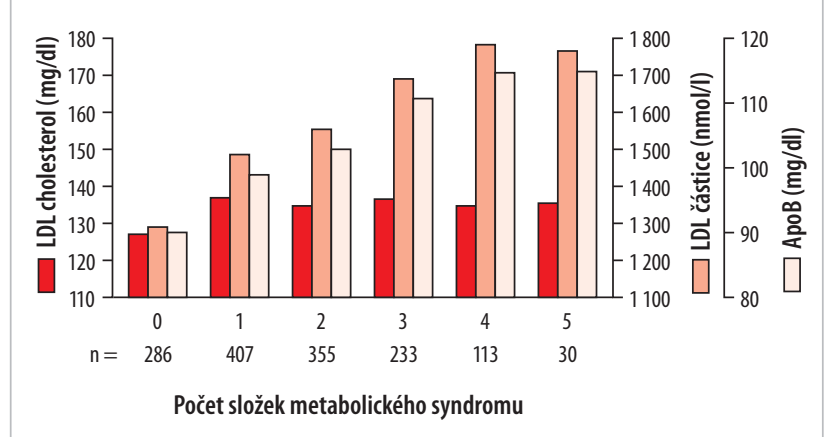

Obrázek 3 Údaje od 2993 účastníků Framinghamské studie ukazují významné zvýšení koncentrací apolipoproteinu B ( $p<0,0001$ pro tento trend) a koncentrace LDL částic ( $p<0,0001$ pro trend) se zvyšujícím se počtem složek metabolického syndromu, koncentrace LDL cholesterolu se měnily mnohem méně ${ }^{36}$

Při převodu koncentrací cholesterolu z mg/dl na mmol/l vynásobte 0,0259 ; při převodu triglyceridů z $\mathrm{mg} / \mathrm{dl}$ na $\mathrm{mmol} / \mathrm{I}$ vynásobte 0,01129 .

ApoB - apolipoprotein B; LDL - lipoproteiny o nízké hustotě mie $^{39}$ zdůrazňují, že je nutné, aby jako součást reziduálního rizika byla terapeuticky ovlivňována hodnota apoB, protože samotná koncentrace LDL cholesterolu neodpovídá přesně aterogenní zátěži dané částicemi přenášejícími apoB. Nedostatek údajů z klinických studií však vede k terapeutickým rozpakům, protože není známo, zda lze koncentraci apoB nejlépe ovlivnit intenzifikací léčby statiny nebo přidáním fibrátu či niacinu $\mathrm{k}$ léčbě statinem.

Bylo také prokázáno, že významným nezávislým prediktorem kardiovaskulárních onemocnění je apolipoprotein C-III (apoC-III), který je součástí některých VLDL a LDL bohatých na triglyceridy. ${ }^{40-48}$ Plazmatické koncentrace apoC-III jsou vyšší u pacientů s aterogenní dyslipoproteinemií, hypertriglyceridemií, metabolickým syndromem, inzulinovou rezistencí a diabetes mellitus 2. typu. ${ }^{41,47,49,50}$ ApoC-III může mít u diabetu zvláštní patologickou úlohu, protože se prostřednictvím prímé aktivace prozánětlivých a aterogenních mechanismů v endotelových buňkách cév a v monocytech ${ }^{54-56}$ podílí na dysfunkci ß-buněk a mikrovaskulárních komplikacích. ${ }^{51-53}$ Ke kardiovaskulárnímu riziku přispívají také jiné apolipoproteiny ve VLDL a LDL, ale o jejich úloze máme méně důkazů než o vlivu apoC-III. ApoA-I a apoA-II, hlavní apolipoproteiny HDL, jsou oba spojovány s potenciálně ateroprotektivními účinky a nižším kardiovaskulárním rizikem..$^{57,58}$

V lipidových klinických studiích byla kombinace poruch metabolismu lipidů a lipoproteinů, která je charakteristická pro metabolický syndrom, spojena s reziduálním kardiovaskulárním rizikem. ${ }^{59}$ Léčba statiny, ani ve vyšších dávkách, neřeší toto reziduální riziko úplně. I když je koncentrace LDL cholesterolu $<70 \mathrm{mg} / \mathrm{dl}(1,81 \mathrm{mmol} / \mathrm{l})$, zůstává vaskulární riziko až o $40 \%$ vyšší v případě nízké koncentrace HDL cholesterolu (<35 mg/dl, 0,90 mmol/l) $)^{60}$ nebo vyšší koncentrace TG (> $200 \mathrm{mg} / \mathrm{dl}, 2,26 \mathrm{mmol} / \mathrm{l}){ }^{61}$

\section{Aterogenní dyslipidemie a mikrovaskulární riziko}

Dyslipidemie se také podílí na patogenezi diabetických mikrovaskulárních komplikací. ${ }^{62}$ Vyšší sérové koncentrace celkového a LDL cholesterolu ${ }^{63-65}$ a TG ${ }^{65}$ mohou mít kauzální úlohu při vzniku retinálních tvrdých exsudátů a diabetické makulopatie a vysoké koncentrace TG byly rovněž spojeny s vyšším rizikem proliferativní diabetické retinopatie. ${ }^{66} \mathrm{~V}$ klinické studii DCCT/EDIC (Diabetes Control and Complications Trial/Epidemiology of Diabetes Interventions and Complications Study) stupeň závažnosti retinopatie pozitivně koreloval s koncentrací TG a negativně s koncentrací HDL cholesterolu. Stejně tak byla zjištěna pozitivní korelace mezi malými a středně velkými VLDL (hodnocenými MR) a skórem ETDRS (Early Treatment Diabetic Retinopathy Study score - ukazatel závažnosti retinopatie) a negativní korelace mezi velkými částicemi HDL cholesterolu a skórem ETDRS. U mužů retinopatie také pozitivně korelovala s koncentrací apoB a LDL. ${ }^{67}$

Vyšší koncentrace triglyceridů a VLDL částic bohatých na TG je spojena s progresí albuminurie, ukazatele nefro- 
patie. ${ }^{68} \mathrm{~V}$ klinické studii UKPDS (United Kingdom Prospective Diabetes Study) byla vyšší koncentrace TG u pacientů s diabetes mellitus 2 . typu nezávisle spojena s incidencí mikroalbuminurie (HR 1,13, 95\% CI 1,07-1,19, $p<0,0001$ ) i makroalbuminurie (HR 1,19, 95\% CI 1,11-1,27, $p<0,0001) .{ }^{69}$ Dodatečné údaje ukazují, že vyšší koncentrace HDL cholesterolu může chránit před nefropatií. ${ }^{70-72}$ Dyslipidemie, zejména vyšší triglyceridemie, vyšší koncentrace celkového a LDL cholesterolu a nižší koncentrace HDL cholesterolu se také podílely na vzniku diabetické neuropatie..$^{73,74}$

\section{Aterogenní dyslipidemie a zánět}

Aterogenní dyslipidemie je také spojena s prozánětlivým stavem, který přispívá k reziduálnímu vaskulárnímu riziku. Experimentální klinické studie prokazují, že VLDL částice bohaté na triglyceridy působí prozánětlivě prostřednictvím nukleárního faktoru kappa B (NFkB), který má klíčovou roli v regulaci celého spektra prozánětlivých genů, jež přispívají $\mathrm{k}$ dysfunkci endotelu a oxidačnímu stresu. ${ }^{75,76}$ ApoC-III má přímé nežádoucí účinky na endotelové buňky cév a monocyty a aktivuje prozánětlivé a proaterogenní cytokiny. ${ }^{54-56}$ Částice VLDL a LDL izolované u pacientů s diabetem 2. typu nebo metabolickým syndromem jsou náchylnější $\mathrm{k}$ lipolýze prostřednictvím cirkulující a subendoteliální fosfolipázy $\mathrm{A}_{2}$ skupiny $\mathrm{V},{ }^{77}$ což vede ke zvýšení koncentrace neesterifikovaných mastných kyselin a lysofosfatidylcholinu v lipoproteinech, a tedy ke zhoršení prozánětlivého stavu. Vyšší celkové hodnoty ukazatelů chronického zánětu nízkého stupně (tj. vysoce senzitivní C-reaktivní protein) a zánětlivé cytokiny se také účastní hlavních kvalitativních změn HDL, které vedou k oslabení ateroprotektivních funkcí včetně ochrany LDL proti oxidační modifikaci. ${ }^{78,79}$

Vyšší koncentrace triglyceridů je navíc spojena s aktivací koagulační kaskády a supresí fibrinolýzy. Postprandiální lipoproteiny bohaté na TG aktivují faktor VII, ${ }^{80,81}$ který je rizikovým faktorem ICHS. ${ }^{82,83}$ Kromě toho bylo prokázáno, že aktivita inhibitoru aktivátoru plasminogenu-1 (PAI-1) spojená s rizikem infarktu myokardu ${ }^{84}$ pozitivně koreluje s koncentracemi částic VLDL bohatých na triglyceridy. ${ }^{85}$ Experimentální studie prokazují, že VLDL zvyšují tvorbu a sekreci PAI-1 prostřednictvím stimulace genové exprese vaskulárního PAI-1 a syntézy proteinů. ${ }^{86}$

Tyto údaje ukazují, že je nutné zvýšit povědomí o důležitosti aterogenní dyslipidemie pro reziduální vaskulární riziko, stejně jako poskytnout informace pro účinné vedení léčby tohoto stavu.

\section{Léčebné postupy ke snížení reziduálního vaskulárního rizika \\ Modifikace životního stylu \\ Dieta}

Dietní doporučení ustupují od doporučeného obsahu živin ve stravě a výrazněji podporují zdravé dietní návyky. ${ }^{87}$
Tradiční středomořská strava, běžná např. v Řecku a v jižní Itálii, je spojena s dlouhověkostí, ${ }^{88}$ nízkou kardiovaskulární mortalitou, ${ }^{89}$ nižším výskytem diabetu 2 . typu ${ }^{90}$ a nízkou incidencí velkého spektra chronických chorob, včetně revmatoidní artritidy, ${ }^{91}$ Parkinsonovy ${ }^{92}$ a Alzheimerovy nemoci. ${ }^{93}$ Trichopoulou a spol. ${ }^{94}$ definovali jádro středomořské stravy, kam patř́ konzumace zeleniny, ovoce, ryb, celozrnných potravin, luštěnin, nenasycených tuků, mírný př́ijem alkoholu a omezený př́jem červeného masa. V klinických studiích snižovala tato strava krevní tlak a zlepšovala dyslipidemii. ${ }^{95}$ Středomořské stravovací návyky se velmi podobají dietám DASH a OmniHeart testovaným v USA, které vedou k podstatnému snížení krevního tlaku a LDL cholesterolu. ${ }^{96}$ Vyšší obsah nenasycených mastných kyselin nebo bílkovin v dietě OmniHeart vedl k lepšímu účinku diety na LDL cholesterol, TG i na krevní tlak (tabulka 2). ${ }^{96}$ Také př́jem sodíku ve stravě by měl být co nejnižší, aby se zabránilo vzniku hypertenze nebo napomohlo v její léčbě. ${ }^{97}$

Randomizované kontrolované klinické studie prokázaly, že polynenasycené mastné kyseliny $\omega-6$ a $\omega-3$ zlepšují kardiovaskulární rizikové faktory a snižují výskyt kardiovaskulárních příhod. ${ }^{98-102}$ Kyselina linolová, $\omega-6$ mastná kyselina nacházející se $\mathrm{v}$ mnoha rostlinných olejích včetně sójového, slunečnicového, světlicového a kukuřričného, zlepšuje inzulinovou senzitivitu, snižuje LDL cholesterol a mezi živinami nejvýrazněji snižuje poměr LDL/HDL cholesterolu. ${ }^{103}$ Mononenasycené mastné kyseliny, které se nacházejí např́klad v olivovém nebo řepkovém oleji a ořeších, zlepšují inzulinovou senzitivitu a snižují poměr LDL/HDL. ${ }^{104}$ Olivový olej, zejména panenský, obsahuje další rostlinné chemické látky, které mají př́íznivé účinky na kardiovaskulární rizikové faktory a související fyziologické parametry, ${ }^{105}$ řepkový olej obsahuje $\alpha$-linolenovou kyselinu, $\omega$-3 mastnou kyselinu, která má významné ochranné kardiovaskulární účinky a snižuje výskyt koro-

\section{Tabulka 2 Vliv kvality stravy - klíčová zjištění z klinické} studie OmniHeart ${ }^{96}$

Porovnávala modifikovanou, na cukry bohatou dietu vycházející z diety DASH, ${ }^{97}$ s preferencí ovoce, zeleniny, potravin s vysokým obsahem bílkovin (fazolí, celozrnného pečiva, ořechů, nízkotučných mléčných výrobků, ryb a drůbeže) a nenasycených mastných kyselin (MK) s dietou s vysokým obsahem bílkovin (přibližně 50 \% rostlinného původu) a dietou bohatou na nenasycené mastné kyseliny (hlavně mononenasycené MK). Tělesná hmotnost byla konstantní.

- Jak dieta bohatá na bílkoviny, tak dieta s nenasycenými tuky vedla ke snížení krevního tlaku oproti dietě bohaté na cukry.

- Jak dieta bohatá na bílkoviny, tak dieta s nenasycenými MK významně snižila koncentraci TG, celkového a non-HDL cholesterolu oproti dietě bohaté na cukry.

- Dieta s nenasycenými MK zvýšila koncentraci HDL cholesterolu oproti jiným dietám.

- Částečná náhrada sacharidů proteiny nebo mononenasycenými MK může zlepšit riziko KVO.

HDL - lipoproteiny o vysoké hustotě (high-density lipoprotein), KVO kardiovaskulární onemocnění, MK - mastné kyseliny, TG - triglyceridy 
nárních příhod. ${ }^{106,107}$ Hojné použivání různých prrírodních tekutých rostlinných olejů je snad nejlepším dietním opatřením vedoucím ke zlepšení kardiovaskulárního rizika a diabetu.

Je jasné, že zdravější strava příznivě a významně ovlivňuje dyslipidemii a hypertenzi, dokonce i u obézních pacientů, kteří nehubnou. ${ }^{96,108}$ Tato nedoceňovaná skutečnost by měla stimulovat lékaře a jejich obézní pacienty, aby zlepšili kvalitu svého jídelníčku, i když nemohou zhubnout.

\section{Cvičení}

Cvičení je rovněž základním kamenem prevence a léčby kardiovaskulárních onemocnění, diabetu 2. typu a metabolického syndromu (tabulka 3). Epidemiologické studie naznačily, že fyzická aktivita může snižovat kardiovaskulární riziko a diabetes mellitus 2 . typu až o $50 \% .{ }^{109,110}$ U diabetiků byla vyšší fyzická aktivita významně a nepřímo úměrně spjata $s$ mortalitou. ${ }^{11}$ Ve studii Women's Health Study fyzická aktivita snížila riziko ICHS v důsledku vyššího BMI (BMI $\left.\geq 25 \mathrm{~kg} / \mathrm{m}^{2}\right)$ u žen ve středním a pokročilém věku, i když ho zcela neodstranila. ${ }^{112}$

Pravidelná fyzická aktivita zlepšuje inzulinovou senzitivitu $^{113}$ a kontrolu glykemie ${ }^{114,115}$ a má výrazný příznivý účinek na profil lipoproteinů včetně HDL cholesterolu, poměru celkového a HDL cholesterolu a TG, dokonce i bez úbytku tělesné hmotnosti. ${ }^{116,117}$ Zlepšení profilu lipidů a lipoproteinů $\mathrm{v}$ důsledku cvičení bylo zaznamenáno u starších dospělých, ${ }^{118}$ dětí i dospívajících. ${ }^{19}$ Kombinace aerobního a silového cvičení je nejvýhodnější u pacientů s aterogenní dyslipidemií a jinými složkami metabolického syndromu, a to v důsledku redukce tukové tkáně, nárůstu svalové hmoty a zlepšení funkce myocytů. ${ }^{120}$ Pravidelná fyzická námaha navíc kromě těchto a jiných př́nosů pro tělesné zdraví (tabulka 3) 109,112,121,122 $^{1}$ zlepšuje psychický pocit zdraví a pohody. ${ }^{123}$

Frekvence cvičení je pravděpodobně důležitější než jeho intenzita, ${ }^{115}$ ačkoli některé studie ukazují, že tyto faktory jsou stejně důležité. ${ }^{124}$ Nejoblíbenější aktivitou pro prevenci diabetu 2. typu ${ }^{125}$ nebo zlepšení metabolického syndromu se zdá být cvičení střední intenzity, jako např́íklad každodenní rychlá chůze po dobu 30 minut nebo déle. ${ }^{126}$

\section{Alkohol}

Kardioprotektivní účinek mírné až střední konzumace alkoholu (jeden drink denně pro ženy a jeden až dva drinky

\section{Tabulka 3 Důležitost pravidelné fyzické aktivity}

- Př́znivé účinky na inzulinovou senzitivitu a kompenzaci glykemie

- Př́znivé účinky na aterogenní dyslipidemii

- Př́znivé účinky na kontrolu hmotnosti

- Zlepšení krevního tlaku a zdraví kostí, sní̌ení aterosklerotického rizika KVO stejně jako psychologický př́nos

- Cvičení střední intenzity (rychlá chůze po dobu nejméně 30 minut denně) snižuje riziko diabetes mellitus 2. typu.

- Frekvence cvičení je důležitější než jeho intenzita.

KVO - kardiovaskulární onemocnění denně pro muže) je uznáván. Je zprostředkován převážně zlepšením inzulinové senzitivity a zvýšením koncentrace HDL cholesterolu. ${ }^{127}$ Je však nutné si uvědomit, že nadměrná konzumace alkoholu je spojena s hypertriglyceridemií, ${ }^{128,129}$ zejména $\mathrm{v}$ důsledku vyšší syntézy částic VLDL bohatých na triglyceridy. ${ }^{129}$ Vzhledem k nedostatku údajů $\mathrm{z}$ randomizovaných studií se konzumace alkoholu běžně nedoporučuje.

V souladu s dostupnými klinickými důkazy je dodržování zásad zdravého životního stylu spojeno s poklesem kardiovaskulárního rizika a reziduálního vaskulárního rizika u pacientů, kteří jsou již léčeni statiny nebo antihypertenzivy. To podporují velké prospektivní klinické studie zaměřené na dodržování zdravého životního stylu. V klinické studii Health Professionals Follow-up Study ${ }^{130}$ provedené u 42847 mužů ve věku 40-75 let bez kardiovaskulárních onemocnění na počátku se zjistilo, že dodržováním zásad zdravého životního stylu (zdravá strava s pravidelným cvičením a střídmou konzumací alkoholu, nekouření a udržování BMI < 25) by mohlo zabránit vzniku $68 \%$ koronárních př́ihod u mužů léčených statiny. Avšak pouze 2-4 \% pacientů této klinické studie bylo schopno dosáhnout zásad tohoto životního stylu a dodržovat je. Přestože má tento postup významnou úlohu ve snížení reziduálního vaskulárního rizika, bude proto $\mathrm{v}$ důsledku nízké míry dodržování v průběhu delšího časového období nejspíše doplňkem jiné léčebné intervence.

\section{Farmakologické postupy ke snížení vaskulárního rizika}

Zatímco statiny prokazatelně snižují koncentrace non-HDL cholesterolu a apoB, jejich účinky na zvýšení koncentrace HDL cholesterolu a snížení triglyceridů nejsou tak výrazné a závisejí na dávce a typu dyslipidemie. Dalšího snížení LDL cholesterolu lze dosáhnout inhibitory absorpce cholesterolu, jako je ezetimib, nebo inhibitory reabsorpce žlučových kyselin, jako jsou pryskyřice. Výskyt kardiovaskulárních onemocnění snižují také sekvestranty žlučových kyselin, jako je např́klad cholestyramin, ${ }^{131}$ a tato skupina látek je již dlouho zavedenou součástí léčebných postupů. Účinnost a bezpečnost ezetimibu však potvrdí až výsledky velkých klinických studií. Nedávno byla zkoušena kombinace simvastatinu a ezetimibu v placebem kontrolované klinické studii léčby aortální stenózy. ${ }^{132}$ Výsledky neprokázaly snížení primárního cílového ukazatele u náhrady aortální chlopně $(28,3 \%$ vs. $29,9 \%$ s placebem; HR 1,$00 ; 95 \%$ CI $0,84-1,18 ; p=0,97)$, ale významné snížení ischemických koronárních příhod (HR 0,78; 95\% CI 0,63-0,97; $p=0,02$ ). Protože byl ezetimib podáván $\mathrm{v}$ kombinaci se simvastatinem a součástí studie nebyla kontrolní skupina s monoterapií simvastatinem, nelze stanovit, zda př́nos ezetimibu doplňoval dobře známý účinek statinu. Kromě toho byla v léčené skupině vyšší incidence úmrtí v důsledku nádorových onemocnění oproti skupině s placebem. Toto zjištění připisovali autoři náhodě. ${ }^{132}$ Následná analýza údajů o nádorových onemocněních ze tří klinických studií s ezetimibem nepodala důkaz, že by byl ezetimib spojen s vyšší náchyl- 
ností k nádorovým onemocněním. ${ }^{133}$ Přesto se musí ezetimib používat se zvýšenou opatrností. ${ }^{134}$

Lze tedy shrnout, že epidemiologické údaje podporují spojitost nízké koncentrace HDL cholesterolu nebo vyšší koncentrace triglyceridů s kardiovaskulárním rizikem. Skupina autorů však uznává, že nejsou $\mathrm{k}$ dispozici žádné přesné údaje, které by definitivně prokázaly, že je každý z těchto faktorů cílem pro modifikace kardiovaskulárního rizika. Na základě epidemiologických souvislostí odborný konsensus poukazuje na roli léčby trvale vyšších koncentrací TG a nízké koncentrace HDL cholesterolu u pacientů léčených statiny. Cílových hodnot non-HDL cholesterolu lze u těchto pacientů dosáhnout modifikací životního stylu a přidáním fibrátu, niacinu nebo $\omega$-3 mastných kyselin. ${ }^{7-11}$ Vyvíjí se také léčba zaměřená na složky aterogenní dyslipidemie, jako např́iklad blokátory endokanabinoidního receptoru 1 a inhibitory cholesterol ester transfer proteinu (CETP).

\section{Agonisté PPARa}

Jaderné receptory PPAR (peroxisome proliferator-activated receptors) jsou nukleární transkripční faktory, které mají důležitou úlohu $\mathrm{v}$ regulaci lipidového metabolismu, homeostáze glukózy a v zánětlivých procesech. Existují tř̀i izotypy PPAR: $\alpha, \gamma$ a $\beta$ (také známé jako $\delta$ ). $V$ př́tomnosti známého ligandu vytvářejí specifické izotypy PPAR heterodimery s retinoidním receptorem X (RXR), dalším transkripčním faktorem aktivovaným ligandy. Tento komplex PPAR-RXR poté rozpoznává specifické elementy PPAR a váže se na ně, což vede $k$ modulaci exprese cílových genů ovlivňujících $\mathrm{v}$ prŕípadě izotypu $\alpha$ oxidaci mastných kyselin, metabolismus lipidů, energetickou rovnováhu a zánět. ${ }^{135}$

\section{Účinky na aterogenní dyslipidemii}

Hlavním účinkem všech fibrátů je snížení koncentrace triglyceridů (cca o 20-30 \% v nedávných větších klinických studiích, ${ }^{136-139}$ ačkoli podstatnější snížení mohou být patrna $\mathrm{u}$ pacientů $\mathrm{s}$ nadprůměrnou koncentrací TG před léčbou) ${ }^{140,141}$ včetně postprandiálních TG a remnantních lipoproteinových částic. ${ }^{135,140-143}$ Fibráty také zvyšují koncentraci HDL cholesterolu, a to většinou o 5-10 $\%,{ }^{136-139}$ prostřednictvím stimulace exprese apoA-I a apoA-II. ${ }^{140,144}$ Fenofibrát rovněž snižuje koncentraci LDL cholesterolu, více u jedinců s průměrnou než vysokou počáteční koncentrací triglyceridů. ${ }^{145}$ Jak fenofibrát, tak gemfibrozil také snižují koncentrace apoC-III. ${ }^{146-149}$ Kromě toho mají agonisté PPARa protizánětlivé účinky. ${ }^{140,150}$

\section{Vliv na makrovaskulární riziko}

Dodnes bylo provedeno několik velkých randomizovaných klinických studií s fibráty a jejich výsledky jsou shrnuty v tabulce 4. ${ }^{136-139,151-156}$ Celkové výsledky předchozích klinických studií s clofibrátem ${ }^{151,152,157,158}$ ukázaly prŕznivé účinky clofibrátu na klinické výsledky, ačkoli v př́padě studie Světové zdravotnické organizace (WHO) bylo významné snížení nefatálního IM (o $25 \%, p<0,05)$ při léčbě clofibrátem zastíněno zvýšením mortality v důsledku nekardiovaskulárních chorob, a to zejména maligních onemocnění gastrointestinálního systému. ${ }^{152}$ Dlouhodobá účinnost a bezpečnost mnoha hypolipidemik měla být zhodnocena ve studii Coronary Drug Project, ${ }^{151}$ ale pouze dvě látky clofibrát a niacin - byly podávány po celou dobu klinické studie (viz oddíl Niacin). Nicméně tato klinická studie nepřinesla důkaz o významném př́nosu ke snížení mortality v celkové populaci studie (tabulka 4). Nízká účinnost clofibrátu při modifikaci lipidů v těchto klinických studiích a obavy z nežádoucích účinků clofibrátu v klinické studii $\mathrm{WHO}^{152}$ vedly $\mathrm{k}$ následnému stažení clofibrátu $\mathrm{z}$ klinické praxe. Z novějších klinických studií byly dvě (Helsinki Heart Study ${ }^{136}$ a Veterans Affairs HDL Intervention Trial ${ }^{137}$ ) pozitivní, zatímco další klinické studie (BIP [Bezafibrate Infarction Prevention] ${ }^{138}$ a FIELD [Fenofibrate Intervention and Event Lowering in Diabetes] ${ }^{139}$ ) neprokázaly signifikantní účinek na jejich sledované primární ukazatele. Za povšimnutí stojí, že post hoc analýza těchto klinických studií prokázala, že relativní snížení rizika kardiovaskulárních prríhod bylo statisticky významné u pacientů s aterogenní dyslipidemií (vysoká koncentrace TG, nízká koncentrace HDL cholesterolu či obojí), metabolickým syndromem nebo diabetes mellitus 2. typu a významně vyšší než u jedinců, kteří tyto poruchy neměli, ${ }^{139,153-156}$ ačkoli formální testy interakcí nebyly významné.

Klinická studie FIELD (Fenofibrate Intervention and Event Lowering in Diabetes), ${ }^{139}$ dosud nejrozsáhlejší klinická studie s fibráty zahrnující přibližně 10000 pacientů, ilustruje možnosti a nejistoty panující ohledně použití fibrátů. Léčba fenofibrátem nesnížila signifikantně riziko primárního cílového ukazatele (nefatální IM a úmrtí na ICHS) (snížení RR o $11 \%, p=0,16$ ). Přestože bylo snížení rizika primárního a sekundárního cílového ukazatele (celkové kardiovaskulární příhody) naprosto shodné, vzhledem $\mathrm{k}$ většímu počtu kardiovaskulárních příhod (612 s fenofibrátem vs. $683 \mathrm{~s}$ placebem) oproti koronárním příhodám (256 vs. 288) bylo toto snížení významné pouze v př́padě sekundárního sledovaného ukazatele $(p=0,035)$. Interpretace výsledků je také zkreslena použitím statinů nad rámec studie, které bylo disproporčně vyšší ve skupině s placebem ( $17 \%$ vs. $8 \%$ ) průměrně v celém období klinické studie. Pro úpravu této odlišnosti byly použity různé statistické metody. Metoda uvedená v protokolu, která využívala na čase závislé úpravy pro přechod na jiná hypolipidemika, přinesla odhadované snížení rizika kardiovaskulárních př́ihod o $9 \%,{ }^{159}$ které autoři popsali jako paradoxní, protože bylo nižší než výsledek analýzy intention-to-treat, který činil 11 \%. Alternativní metoda, která využívala fixní kovariát pro hypolipidemickou léčbu, přinesla snížení o $19 \%{ }^{139}$ Autoři také použili jednoduchý způsob k odhadu účinku nerovnoměrné léčby statiny, který předpokládal, že léčba statiny snížila riziko kardiovaskulárních př́ihod přibližně o jednu třetinu, a to vedlo ke snížení rizika ve skupině s fenofibrátem $\mathrm{v}$ rozmezí $17-20 \%{ }^{139}$ Iniciativa $\mathrm{R}^{3} \mathrm{i}$ uznává, že pro konečné stanovení, zda má léčba fibráty opravdu další prrínos u pacientů s aterogenní dyslipidemií, metabolickým syndromem nebo diabetem 2. typu oproti obecné populaci jedinců s vysokým rizikem kardiovasku- 
Tabulka 4 Účinek léčby fibráty na závažné koronární a kardiovaskulární př́hody (jak definuje tabulka) v klinických studiích s fibráty

\begin{tabular}{|c|c|c|c|c|c|c|}
\hline \multicolumn{7}{|c|}{ A. Primární výsledky získané od všech pacientů } \\
\hline \multirow[t]{2}{*}{$\begin{array}{l}\text { Klinická } \\
\text { studie }\end{array}$} & \multirow[t]{2}{*}{ Populace pacientů } & \multirow[t]{2}{*}{ Cílové ukazatele } & \multicolumn{2}{|c|}{$\begin{array}{l}\text { Absolutní počet } \\
\text { příhod (\%) }\end{array}$} & \multirow[t]{2}{*}{$\begin{array}{c}\text { Snížení relativního } \\
\text { rizika (\%) }\end{array}$} & \multirow[t]{2}{*}{ Hodnota $p$} \\
\hline & & & Kontrola & Fibráty & & \\
\hline \multirow[t]{3}{*}{$\mathrm{WHO}^{152}$} & 7194 mužů bez ICHS s hodnotou & Závažné koronární příhody & 5,8 & 4,7 & 20 & $<0,05$ \\
\hline & cholesterolu v horní třetině, kteří & (nefatální IM + úmrtí na ICHS) & & & & \\
\hline & dokončili pětiletou léčbu & Nefatální IM & 4,8 & 3,7 & 25 & $<0,05$ \\
\hline \multirow[t]{2}{*}{$\mathrm{CDP}^{151}$} & 3892 mužů s ICHS (1 103 na clofibrátu & Závažné koronární príhody & NA & NA & 9 & 0,12 \\
\hline & vs. 2789 na placebu) & Mortalita & 20,9 & 20,0 & 4 & 0,55 \\
\hline \multirow[t]{2}{*}{$\mathrm{HHS}^{136}$} & 4081 mužů bez ICHS & Fatální + nefatální IM a úmrtí na ICHS & 4,1 & 2,7 & 34 & $<0,02$ \\
\hline & a non-HDL cholesterolu $\geq 5,18 \mathrm{mmol} / \mathrm{l}$ & & & & & \\
\hline \multirow[t]{2}{*}{ VA-HIT ${ }^{137}$} & 2531 mužů s ICHS a nízkým & Nefatální IM + úmrtí na ICHS & 21,7 & 17,3 & 22 & 0,006 \\
\hline & HDL cholesterolem $(<1,04 \mathrm{mmol} / \mathrm{l})$ & Nefatální IM + úmrtí na ICHS + CMP & 26,0 & 20,4 & 24 & $<0,001$ \\
\hline $\mathrm{BIP}^{138}$ & $\begin{array}{l}3090 \text { mužů a žen s předchozím IM } \\
\text { nebo anginou }\end{array}$ & $\begin{array}{l}\text { Fatální nebo nefatální IM } \\
\text { nebo náhlá smrt }\end{array}$ & 15,0 & 13,6 & 7,3 & 0,24 \\
\hline \multirow[t]{2}{*}{ FIELD ${ }^{139}$} & 9795 mužů a žen s DM 2. typu & Nefatální IM + úmrtí na ICHS & 5,9 & 5,2 & 11,0 & 0,16 \\
\hline & & Celkové koronární príhody & 13,9 & 12,5 & 11,0 & 0,035 \\
\hline
\end{tabular}

\begin{tabular}{|c|c|c|c|c|c|c|}
\hline \multirow[t]{2}{*}{$\begin{array}{l}\text { Klinická } \\
\text { studie }\end{array}$} & \multirow[t]{2}{*}{ Populace pacientů } & \multirow[t]{2}{*}{ Cílové ukazatele } & \multicolumn{2}{|c|}{$\begin{array}{l}\text { Absolutní počet } \\
\text { př́íhod (\%) }\end{array}$} & \multirow[t]{2}{*}{$\begin{array}{c}\text { Snížení relativního } \\
\text { rizika }(\%)\end{array}$} & \multirow[t]{2}{*}{ Hodnota $p$} \\
\hline & & & Kontrola & Fibráty & & \\
\hline $\mathrm{HHS}^{153}$ & $\begin{array}{l}\mathrm{TG} \geq 2,31 \mathrm{mmol} / \mathrm{l}, \mathrm{HDL} \text { cholesterol } \\
<1,04 \mathrm{mmol} / \mathrm{l}+\mathrm{BMl}>26 \mathrm{~kg} / \mathrm{m}^{2}\end{array}$ & $\begin{array}{l}\text { Fatální + nefatální IM a úmrtí } \\
\text { na ICHS }\end{array}$ & NA & NA & 78 & 0,002 \\
\hline \multirow[t]{2}{*}{ VA-HIT ${ }^{154}$} & 769 (30 \%) s DM & Nefatální IM + úmrtí na ICHS & 36,1 & 24,5 & 32 & $<0,001$ \\
\hline & 1185 (47 \%) s TG $\geq 1,7 \mathrm{mmol} / \mathrm{l}$ & $+\mathrm{CMP}$ & 27,0 & 20,0 & 27 & 0,01 \\
\hline \multirow[t]{2}{*}{$\mathrm{BIP}^{155}$} & 459 (15\%) s TG > 2,26 mmol/l & $\begin{array}{l}\text { Fatální nebo nefatální IM } \\
\text { nebo náhlá srdeční smrt }\end{array}$ & 19,7 & 12,0 & 39,5 & 0,02 \\
\hline & 1470 (48 \%) s metabolickým syndromem ${ }^{1}$ & & 18,4 & 14,1 & 25,0 & 0,03 \\
\hline FIELD ${ }^{156}$ & $\begin{array}{l}\text { Nízká hodnota HDL cholesterolu² } \\
\text { a TG } \geq 2,26 \mathrm{mmol} / \mathrm{l}\end{array}$ & Celkové koronární príhody & 17,8 & 13,5 & 26 & 0,01 \\
\hline
\end{tabular}

${ }_{1}^{1}$ Nejméně tři z následujících: glukóza nalačno $\geq 6,11 \mathrm{mmol} / \mathrm{I}$ nebo současné použití PAD; TG $\geq 1,7 \mathrm{mmol} / \mathrm{l}, \mathrm{HDL}$ cholesterol $<1,04 \mathrm{mmol} / \mathrm{l}$ u mužů a $<1,3 \mathrm{mmol} / \mathrm{l}$ u žen, systolický krevní tlak $\geq 130 \mathrm{~mm} \mathrm{Hg}$ nebo diastolický krevní tlak $\geq 85 \mathrm{~mm} \mathrm{Hg}$ nebo body mass index $\geq 28,0 \mathrm{~kg} / \mathrm{m}^{2}$;

${ }^{2}$ nízká hodnota $\mathrm{HDL}$ cholesterolu definována jako $<1,04 \mathrm{mmol} / \mathrm{l}$ u mužů a $<1,3 \mathrm{mmol} / \mathrm{l}$ u žen; hodnoty $p$ se vztahují ke kontrolám (placebo).

$\mathrm{BIP}=$ Bezafibrate Infarction Prevention study, CMP = cévní mozková příhoda, FIELD = Fenofibrate Intervention and Event Lowering in Diabetes study, HHS = Helsinki Heart Study, ICHS = ischemická choroba srdeční, IM = infarkt myokardu, KV = kardiovaskulární, KVO = kardiovaskulární onemocnění, VA-HIT = Veterans Affairs HDL Intervention Trial, WHO = Světová zdravotnická organizace (World Health Organization)

lárního onemocnění, je nutné provést souhrnnou analýzu klinických studií s fibráty.

\section{Zvážení bezpečnosti}

Klinické studie poukazují na synergický účinek kombinace fibrátu a statinu (tabulka 5). ${ }^{160,161}$ Společně s důkazy z dostupných klinických studií zaměřených na monoterapii fibráty mohou tedy podpořit skutečnost, že kombinace statinu a fibrátu může poskytnout další klinický přínos, ačkoli to musí být potvrzeno studiemi hodnotícími klinické prríhody. Kromě toho existují také obavy ohledně snášenlivosti, zejména pokud jde o potenciální vyšší toxické působení na kosterní svalstvo, protože jak monoterapie statiny, tak fibráty je spojena s rizikem myopatie. ${ }^{162,163}$ Epidemiologické studie odhadují 5,5krát vyšší riziko myopatie při monoterapii fibráty oproti léčbě statiny, ${ }^{164}$ ačkoli absolutní riziko obou skupin léčiv se považuje za nízké. Nicméně mezi jednotlivými fibráty existují určité rozdíly v tomto riziku, což zdůraznily bezpečnostní údaje $\mathrm{z}$ databáze systému hlášení nežádoucích účinků amerického FDA (Úřadu pro kontrolu potravin a léků) (1998-2002). Incidence př́padů rabdomyolýzy a myopatie (souhrnný název pro myalgii, myositidu a myopatii) byla $15 k$ rát a $33 k$ rát vyšší při kombinaci gemfibrozilu a statinu (vyjma vyřazeného cerivastatinu) než při použití fenofibrátu a statinu. ${ }^{165}$ Důvodem je pravděpodobně nižší kompetice mezi statiny a fenofibrátem 
Tabulka 5 Účinky kombinované léčby modifikující lipidy oproti monoterapii statinem

\section{Fibrát plus statin}

- Další snižení TG, apoB a non-HDL a VLDL cholesterolu

- Další zvýšení HDL cholesterolu

- Vzácně vyšší riziko myopatie, vyšší u gemfibrozilu než u fenofibrátu

Niacin plus statin

- Další snižení TG a LDL cholesterolu

- Další zvýšení HDL cholesterolu

- Pokles Lp(a)

- S niacinem běžně zrudnutí kủže, vzácně na dávce závislá hepatotoxicita, hyperurikemie a dna

Omega-3 mastné kyseliny plus statin

- Další snížení TG a VLDL cholesterolu

ApoB - apolipoprotein B, HDL - lipoproteiny o vysoké hustotě, Lp(a) - lipoprotein(a), TG - triglyceridy, VLDL - lipoproteiny o velmi nízké hustotě

oproti gemfibrozilu kvůli specifickým glukuronidázám, hlavním jaterním enzymům metabolismu léků. ${ }^{166} \mathrm{Za}$ povšimnutí kromě toho stojí, že v klinické studii FIELD nebyly u 890 pacientů, kteří v průběhu studie užívali kombinaci fenofibrát plus statin, zjištěny žádné př́pady rabdomyolýzy. ${ }^{139}$ Nedávný odborný konsensus americké společnosti National Lipid Association ${ }^{167}$ udává, že riziko myopatie je př̀ použití fenofibrátu v kombinaci se statiny nízké, zejména pokud je dávka statinu v nižším rozmezí. Avšak zvážit by se měl také trend fenofibrátu ke zvyšování sérové koncentrace kreatininu, který byl prokázán v klinické studii FIELD. Tento účinek byl reverzibilní v průběhu osmi týdnů po přerušení léčby, ${ }^{139}$ což znamenalo, že renální funkce nebyla porušena trvale. V této i jiné klinické studii u diabetiků 2. typu byl navíc fenofibrát spojen s nižší progresí albuminurie. ${ }^{139,168}$

Je jasné, že je nutné provedení dalších klinických studií. $\mathrm{V}$ řešení této problematiky pomohou výsledky klinické studie ACCORD (Action to Control Cardiovascular Risk in Diabetes). ${ }^{169}$ Cílem této zaslepené klinické studie je porovnat, zda je kombinace simvastatin plus fibrát (fenofibrát) účinnější ve snížení kardiovaskulárních př́ihod než kombinace statin plus placebo v kohortě přibližně 5000 pacientů s diabetes mellitus 2. typu s definovanou kontrolou glykemie a existujícími klinickými nebo subklinickými kardiovaskulárními onemocněními nebo rizikovými kardiovaskulárními faktory. Pacienti byli randomizováni bud' $\mathrm{k}$ uživání simvastatinu (v dávce až $40 \mathrm{mg} / \mathrm{d}$, je-li to nutné $\mathrm{k}$ dosažení cílové hodnoty LDL cholesterolu $<100 \mathrm{mg} / \mathrm{dl}[2,59 \mathrm{mmol} / \mathrm{l}]$ ) plus placeba, nebo $\mathrm{k}$ léčbě vedoucí $\mathrm{k}$ dosažení stejné cílové hodnoty LDL cholesterolu s použitím simvastatinu plus fenofibrátu. Tato klinická studie také poskytne informace o bezpečnosti této kombinace hypolipidemik. Výsledky se očekávaly na konci roku 2009.

Niacin

Účinky na aterogenní dyslipidemii

Niacin je v současnosti nejsilnější dostupnou látkou zvyšující koncentraci HDL cholesterolu (cca o 20-25 \% při užívání $1,5-2 \mathrm{~g}$ denně $\mathrm{v}$ lékové formě s prodlouženým uvol- ňováním [extended-release - ER]). ${ }^{170,171}$ Niacin snižuje koncentraci LDL cholesterolu přibližně o $10-15 \%$, TG přibližně o 15-25\% a lipoproteinu(a), nezávislého prediktoru ICHS, ${ }^{172-174}$ přibližně o $15-20 \% .{ }^{170,171,175-177}$ Niacin také zvyšuje hodnotu apoA-I přibližně o $10 \% \cdot{ }^{170}$ Účinky ER niacinu na lipidový profil jsou př́mo úměrné dávce $\mathrm{v}$ rozmezí od 0,5 do 2,0 g. ${ }^{170,171,175}$

Přestože byly nalezeny specifické receptory pro niacin ${ }^{178}$ a jejich endogenní ligand ( $\beta$-hydroxybutyrát), ${ }^{179}$ důkazy ukazují, že tyto receptory nezprostředkovávají účinek niacinu na HDL. Dostupné „laboratorní" studie prokazují, že niacin snižuje tvorbu VLDL a LDL, ${ }^{180,181}$ stejně jako katabolismus apoA-I. ${ }^{182}$ Kromě toho studie na zvírecích modelech prokazují, že CETP je nezbytný pro mechanismus zvýšení HDL. ${ }^{183}$ Niacin má také mnoho antiaterotrombotických účinků, které zlepšují funkci endotelu, snižují zánět, zvyšují stabilitu plátu a snižují trombogenicitu. ${ }^{184}$ Niacin doplňuje účinky statinů zlepšením koncentrace LDL a HDL cholesterolu a TG (tabulka 5). ${ }^{185}$

\section{Vliv na makrovaskulární riziko}

Jedinou randomizovanou klinickou studií s niacinem $\mathrm{v}$ monoterapii v rámci koronární prevence je CDP (Coronary Drug Project). U 1119 mužů s předchozím IM, kteří byli randomizováni $\mathrm{k}$ léčbě niacinem (léková forma s okamžitým uvolňováním), bylo zjištěno významné snížení koronárního úmrtí a nefatálního IM o $14 \%(p<0,05)$ za pět let, kdy klinická studie skončila. ${ }^{151}$ Prodloužené sledování mortality ukázalo, že ve skupině užívající niacin bylo zaznamenáno $11 \%$ snížení celkové mortality $(p=0,0004)$, zejména díky poklesu kardiovaskulární mortality (o $12 \%$, $p=0,005) .{ }^{187}$ Př́znivý vliv léčby na riziko mortality byl také patrný u diabetiků při hodnotách glykemie nalačno $\geq 126 \mathrm{mg} / \mathrm{dl}(\geq 6,93 \mathrm{mmol} / \mathrm{l}) .{ }^{188}$ Angiografické zobrazovací studie také prokázaly, že léčba niacinem v kombinaci $\mathrm{s}$ colestipolem, která byla použita $\mathrm{v}$ klinické studii FATS (Familial Atherosclerosis Treatment Study), ${ }^{189}$ nebo v kombinaci se statinem, použité v klinické studii HATS (HDL-Atherosclerosis Treatment Study), ${ }^{190}$ zpomalila progresi koronární aterosklerózy ve srovnání s placebem. Nicméně obě klinické studie se považují za malé a ani jedna studie nezahrnovala pro srovnání rameno monoterapie statinem.

\section{Zvážení bezpečnosti}

Častým problémem je zrudnutí kůže (flush), které významně ovlivňuje přijetí léku a compliance s léčbou. $Z$ tohoto důvodu také mnohdy kliničtí lékaři na použití niacinu dokonce ani nepomyslí. ${ }^{191,192}$ Tento účinek může zmírnit kyselina acetylsalicylová (325 mg dvakrát denně) podávaná jeden den před aplikací první dávky niacinu a dále po celý první měsíc nebo dokud není dosaženo plné dávky niacinu. Nedávno byl vytvořen postup řešení tohoto problému, který představuje kombinaci niacinu ER s laropiprantem, inhibitorem prostaglandinového receptoru $\mathrm{D}_{2}$, který se přímo účastní flushové reakce. ${ }^{193} \mathrm{~V}$ klinických studiích s pacienty se smíšenou dyslipidemií vedla kombinace laropiprantu a ER niacinu k významně menšímu - a méně závažnému - 
zarudnutí př̀i zahájení léčby a v průběhu udržovací léčby. ${ }^{194}$ Avšak dlouhodobá bezpečnost laropiprantu v kombinaci s niacinem musí být ještě stanovena. Tento kombinovaný prrípravek byl schválen pro léčbu dyslipidemie nebo primární hypercholesterolemie v Evropě, ale v USA vydal nedávno FDA jako odpověd' na žádost o registraci tohoto prrípravku odmítavé stanovisko.

Niacin také zvyšuje glykemii prostřednictvím snížení inzulinové senzitivity, i když bylo v klinických studiích prokázáno, že zvýšení glykemie zaznamenané u jednotlivých pacientů bylo možné rychle zvrátit úpravou hypoglykemizující léčby. ${ }^{195}$ Méně často byly při léčbě niacinem hlášeny vyšší koncentrace jaterních enzymů, zvýšení kyseliny močové anebo zhoršení dny. ${ }^{192}$ Po zahájení léčby niacinem může dojít $\mathrm{k}$ novému výskytu diabetu u lidí s metabolickým syndromem, zejména mají-li poruchu glukózové tolerance. ${ }^{196}$ Riziko výskytu diabetu není v současné době jasné a bude dále hodnoceno v probíhajících klinických studiích.

Důkaz, že kombinace niacinu a statinu zlepšuje lipidový profil, ${ }^{186}$ spolu s výsledky studie Coronary Drug Project ${ }^{151,187,188}$ ukazují na potenciální další klinický přínos této kombinované léčby. Je jasné, že je nutné provést další klinické studie. Těmito otázkami se zabývají dvě probíhající randomizované klinické studie sledující výskyt klinických prríhod. V klinické studii AIM-HIGH (Atherothrombosis Intervention in Metabolic Syndrome with Low HDL/High Triglycerides and Impact on Global Health Outcomes) se porovnává kombinace ER niacinu a simvastatinu s monoterapií simvastatinem přibližně u 3300 pacientů s diagnostikovanými vaskulárními chorobami a aterogenní dyslipidemií. ${ }^{197} \mathrm{~V}$ jiné klinické studii HPS2-THRIVE (Heart Protection Study 2 - Treatment of HDL to Reduce the Incidence of Vascular Events) se porovnává kombinace ER niacinu a laropiprantu s placebem asi u 20000 pacientů $s$ anamnézou IM, CMP nebo onemocněním periferních tepen, jejichž koncentrace LDL cholesterolu jsou optimalizovány léčbou statiny. ${ }^{198}$ Výsledky těchto dvou studií se očekávají v roce 2011 a 2012.

\section{Omega-3 mastné kyseliny \\ Ovlivnění aterogenní dyslipidemie}

Omega-3 mastné kyseliny (obsahující eikosapentaenovou kyselinu [EPA, 20 uhlíků] a dokosahexaenovou kyselinu [DHA, 22 uhlíků]) snižují vyšší koncentrace TG a aterogenních remnantů lipoproteinů spojené s aterogenní dyslipidemií. ${ }^{199,200}$ Důkazy klinických studií podporující jejich ochranné účinky proti kardiovaskulárním onemocněním se zakládaly na různých mechanismech, včetně snížení TG, mírného zvýšení HDL cholesterolu, snížení krevního tlaku, změny metabolismu a exprese adhezivních molekul, aktivace PPARa, ${ }^{201}$ snížení proaterogenních cytokinů, interference $s$ metabolismem arachidonové kyseliny a rovněž př́mého účinku na kardiální myocyty, který vedl ke zvýšení prahu ventrikulární arytmie. ${ }^{202} \mathrm{~V}$ USA je nyní k dispozici léková forma na předpis (min. $0,9 \mathrm{~g} \omega-3$ mastných kyselin na $1 \mathrm{~g}$ kapsle oproti $0,2-0,5 \mathrm{~g}$ ve volně prodejných prrípravcích) určená pro pacienty s výrazně zvýšenou koncentrací TG $\geq 5,645 \mathrm{mmol} / \mathrm{l}$ ( $\geq 500 \mathrm{mg} / \mathrm{dl}$ ). V Evropě je léková forma na předpis také indikována jako adjuvantní léčba $\mathrm{v}$ rámci sekundární prevence po infarktu myokardu. ${ }^{203}$ Příznivý účinek modifikace koncentrací lipidů byl zaznamenán po přidání $\mathrm{k}$ léčbě statiny (tabulka 5). ${ }^{204}$

\section{Vliv na makrovaskulární riziko}

Velké klinické studie potvrzují, že suplementace $\omega$-3 mastnými kyselinami (EPA/DHA) jako součásti středomořské stravy ${ }^{99} \mathrm{~V}$ dávce $1 \mathrm{~g} /$ denně ${ }^{100,101}$ má př́iznivé účinky na klinické výsledky, včetně závažných kardiálních příhod a náhlé srdeční smrti. Jde asi spíše o účinky na srdeční rytmus než o účinky na lipidy nebo krevní tlak. ${ }^{205,206}$ Klinická studie JELIS (Japan EPA lipid intervention study) ${ }^{207}$ podpořila předpoklad, že kombinace $\omega-3$ mastných kyselin a statinu může zlepšovat koncentrace lipidů a může představovat další klinický přínos. Suplementace EPA (1 800 mg denně) v kombinaci s terapií statiny v nízkých dávkách (pravastatin 10 mg nebo simvastatin 5 mg denně) ve srovnání s monoterapií statinem snížila koronární př́íhody, aniž by změnila četnost náhlé srdeční smrti. Ačkoli ve skupině EPA klesla koncentrace TG o $9 \%$ (vs. $4 \%$ u kontrol), ani v jedné skupině nebyly zjištěny účinky na celkový, LDL nebo HDL cholesterol. Je zřejmé, že bude nutné provést další klinické studie. Kromě toho stojí za povšimnutí, že v klinické studii GISSI (Gruppo Italiano per lo Studio della Sopravvivenza nell'Infarto miocardico $)^{208}$ bylo nedávno zjištěno, že suplementace $\omega$-3 mastnými kyselinami ( $1 \mathrm{~g}$ denně) může poskytnout malou, ale významnou prríznivou prognostickou výhodu (oproti placebu) ve smyslu mortality (upravené HR $0,91 ; 95,5 \%$ CI $0,833-0,998 ; p=0,041)$ a hospitalizace z kardiovaskulárních důvodů (upravené HR 0,92; 99\% CI 0,849-0,999; $p=0,009$ ) u pacientů se srdečním selháním.

Zavedená antidiabetická léčba, včetně thiazolidindionů rosiglitazonu a pioglitazonu (oba jsou PPAR $\gamma$ agonisté) a metforminu, má různé účinky na lipidy a lipoproteiny. Zatímco pioglitazon a rosiglitazon působí na inzulinovou senzitivu a zánět podobně, ve svých účincích na lipidy se liší. Pioglitazon snižuje koncentraci TG přibližně o 15-20\%, koncentraci HDL cholesterolu zvyšuje přibližně o 10-13\% a má zanedbatelný účinek na LDL cholesterol (bud' beze změny, nebo zvýšení o $5 \%$ ), zatímco rosiglitazon může zvyšovat koncentraci TG o 10-20 \%, HDL cholesterolu o 5-7 \% a LDL cholesterolu o 5-20\%. ${ }^{209}$ Metaanalýzy klinických studií ukazují, že léčba metforminem vede ke snížení koncentrace LDL cholesterolu a TG, a to přibližně o 0,259 mmol/l u LDL cholesterolu a 0,113 mmol/l u TG, na rozdíl od derivátů sulfonylurey druhé generace, které mají minimální účinek na HDL cholesterol nebo nemají žádný. ${ }^{210}$

Zatímco léčba pioglitazonem byla spojena se snížením závažných kardiálních př́ihod u vysoce rizikových pacientů s diabetes mellitus 2 typu, ${ }^{211,212}$ značná nejistota přetrvává, pokud jde o celkové kardiovaskulární účinky agonistů PPAR $\gamma$, a čeká se na údaje $z$ dalších prospektivních klinických studií. Podobně bylo ve středním nebo pozdním kli- 
nickém zkoušení přerušeno podávání několika duálních agonistů PPAR $\alpha / \gamma \mathrm{z}$ důvodu nadměrného výskytu srdečního selhání a jiných kardiovaskulárních příhod připisovaných složce PPAR $\gamma$.

\section{Nová léčba}

Použití agonistů PPAR $\beta / \delta$ budí pozornost $\mathrm{v}$ rámci léčby metabolického syndromu, a to díky jejich účinkům na metabolismus lipoproteinů (zvýšení koncentrace HDL cholesterolu a snížení koncentrace LDL cholesterolu a VLDL-TG), snížení vaskulárního zánětu a regulaci homeostázy glukózy, které byly zjištěny na různých zvírecích modelech. ${ }^{140} \mathrm{Bu}$ doucí postupy se zaměří na vývoj selektivních modulátorů PPAR (SPPARM) se selektivním působením na tkáň a cílové geny se zaměřením na vytvoření duálních agonistů $\operatorname{PPAR} \alpha / \gamma$ a PPAR $\alpha / \delta$, protože ty mohou mít potenciál pro ovlivnění kardiometabolického rizika.

V klinických podmínkách byly zkoumány inhibitory CETP, který podporuje přenos cholesterolu v plazmě z HDL lipoproteinové frakce do proaterogenní LDL lipoproteinové frakce, stejně jako přenos TG z LDL lipoproteinů do HDL lipoproteinů. Torcetrapib, první z těchto inhibitorů, byl stažen $\mathrm{z}$ trhu $\mathrm{v}$ důsledku významného nárůstu mortality (HR 1,58; 95\% CI 1,14-2,19; $p=0,0006)$ a kardiovaskulárních prŕhod (HR 1,25; 95\% CI 1,09-1,44; $p=0,001$ ) u pacientů léčených torcetrapibem plus atorvastatinem (vs. atorvastatin v monoterapii) v klinické studii ILLUMINATE (Investigation of Lipid Level Management to Understand its Impact on Atherosclerotic Events). ${ }^{213} \mathrm{~K}$ tomu došlo navzdory podstatnému zvýšení koncentrace HDL cholesterolu (o $72 \%$ ). Zda byl důvodem tohoto účinku idiosynkratický účinek na systém renin-angiotensin-aldosteron ${ }^{213}$ nebo inhibice CETP samotná, zůstává nejasné. Další klinický vývoj jiných inhibitorů CETP pokračuje, ačkoli první klinické výsledky se neočekávají před rokem 2011 ani po něm.

Selektivní blokátory endokanabinoidního receptoru typu 1 (reverzní agonisté) zvyšují koncentrace HDL cholesterolu, snižují koncentrace TG a snižují tělesnou hmotnost a rovněž mírně zlepšují inzulinovou senzitivitu a koncentrace $\mathrm{HbA}_{1 c}{ }^{214-216}$ První v této skupině, rimonabant, byl zkoumán pro své účinky na progresi koronární aterosklerózy v klinické studii STRADIVARIUS (Strategy to Reduce Atherosclerosis Development Involving Administration of Rimonabant - The Intravascular Ultrasound Study). Za 18 měsíců neprokázal rimonabant vliv na primární cílový ukazatel (zvýšení procentuálního objemu ateromu o $0,25 \%$ oproti $0,51 \%$ při podání placeba, $p=0,22$ ), přestože angiografický výsledek jako sekundární ukazatel (změna celkového objemu ateromu) se významně zlepšil $(p=0,03){ }^{217}$ Objevily se obavy ohledně vyššího rizika neurologických a psychiatrických nežádoucích účinků rimonabantu, ${ }^{218}$ které zamezily jeho schválení v USA. V Evropě je použití rimonabantu možné u obézních pacientů (BMI $\left.\geq 30 \mathrm{~kg} / \mathrm{m}^{2}\right)$ nebo $\mathrm{u}$ jedinců s nadváhou (BMI $\left.\geq 27 \mathrm{~kg} / \mathrm{m}^{2}\right)$ a jinými kardiovaskulárními rizikovými faktory. Léčba je kontraindikována u pacientů s přetrvávající závažnější depresí nebo u pacien- tů užívajících antidepresiva a měla by se přerušit, jestliže se objeví deprese. Tyto údaje zdůrazňují potřebu rozsáhlejšího dlouhodobého sledování bezpečnosti látek z této skupiny.

\section{Snižování reziduálního mikrovaskulárního rizika - má význam léčba modifikující lipidy?}

Intervence prostřednictvím změny životního stylu, zdravé stravy, úbytku hmotnosti a vyšší fyzické aktivity jsou nedílnou součástí vedení léčby diabetu 2. typu a zlepšují hodnoty glykemie, dyslipidemie a krevního tlaku. ${ }^{219}$ Přesto u pacientů přetrvává riziko mikrovaskulárních komplikací. $\mathrm{V}$ klinické studii ADVANCE (Action in Diabetes and Vascular Disease: Preterax and Diamicron Modified Release Controlled Evaluation) $)^{220}$ bylo prokázáno, že intenzivní kompenzace glykemie ( $6,5 \%$ vs. $7,3 \%$ při běžné léčbě) snížila incidenci kombinovaných mikrovaskulárních a hlavních makrovaskulárních příhod o $10 \%$. To bylo dáno převážně významným poklesem výskytu mikroalbuminurie (19,6 \% vs. 23,6 \% při běžné léčbě; snížení RR $21 \%$; 95\% CI 14-27\%; $p<0,0001)$. Nebyl však zaznamenán žádný významný př́nos pro retinopatii. Celkové riziko mikrovaskulárních komplikací nesnížilo ani intenzivní snížení krevního tlaku (snížení RR $9 \%, p=0,16) .{ }^{221}$ Společně s tím oznámila předběžná analýza klinické studie ACCORD zvýšení mortality (zvýšení rizika o $22 \%, p=0,04$ ) spojené $\mathrm{s}$ intenzivní kompenzací glykemie (snížení $\mathrm{HbA}_{1 \mathrm{c}}$ na průměrně 6,4 \% vs. 7,5 \% při běžné léčbě), a to vedlo $\mathrm{k}$ předčasnému ukončení tohoto ramene léčby po průměrné délce sledování 3,5 roku. V klinické studii ACCORD nebyl rovněž prokázán významný přínos pro primární cílový ukazatel (nefatální IM, nefatální CMP nebo úmrtí z kardiovaskulárních prŕčin; RR $10 \%, p=0,16)$ v této vysoce rizikové populaci pacientů. 222 Pozornost se stále více zaměřuje na možnou roli jiných farmakologických intervencí, včetně léčby modifikující lipidy, které by mohly snížit reziduální riziko mikrovaskulárních komplikací.

\section{Diabetická nefropatie}

Přínos léčby statiny pro zpomalení poklesu renální funkce ${ }^{223-225}$ a zlepšení albuminurie u lidí s bazální exkrecí > $30 \mathrm{mg} / \mathrm{den}^{226}$ podporuje velké množství důkazů. Zlepšení odhadované velikosti glomerulární filtrace v souvislosti s použitím statinů bylo významně vyšší u pacientů léčených atorvastatinem v dávce $80 \mathrm{mg}$ oproti dávce $10 \mathrm{mg}$ denně. ${ }^{227}$ Bylo prokázáno, že progresi mikroalbuminurie snížily také gemfibrozil nebo fenofibrát. ${ }^{139,168,228} \mathrm{~V}$ klinické studii FIELD vedla léčba fenofibrátem ke snížení progrese albuminurie (snížení progrese albuminurie o 14 \% a zvýšení regrese albuminurie o $15 \%$ ve srovnání s placebem, $p=0,002)$; fenofibrát byl však také spojen s významným, ale reverzibilním zvýšením sérového kreatininu (viz diskuse v předchozí části). ${ }^{139}$

\section{Diabetická retinopatie}

Výsledky studií se statiny zatím nebyly průkazné. Primárně preventivní klinická studie CARDS (Collaborative Atorva- 
statin Diabetes Study) u diabetiků 2. typu nepřinesla důkazy o významném př́znivém účinku atorvastatinu na progresi diabetické retinopatie. ${ }^{229} \mathrm{~V}$ několika menších studiích byla zjištěna regrese a snížení závažnosti makulárních exsudátů při léčbě statiny. ${ }^{63,230}$

V klinické studii FIELD bylo prokázáno, že fenofibrát měl významný protektivní účinek na vznik diabetické retinopatie a vedl k poklesu nutnosti laserové léčby (předem definovaný terciární cílový ukazatel) o $31 \%(p=0,0003) .{ }^{139}$ Tyto údaje byly dále analyzovány po nezávislém potvrzení nutnosti laserové léčby a byl zjištěn významný přínos pro makulární edém i proliferativní retinopatii (tabulka 6). ${ }^{231}$ Rovněž oftalmologická podstudie FIELD ( $\mathrm{n}=1012)$, ve které byly hodnoceny retinální fotografie s použitím hodnoticích kritérií ETDRS, poskytla určité informace o účincích fenofibrátu na progresi retinopatie (tabulka 6). ${ }^{231}$ Nezdálo se, že by mechanismus(y) těchto účinků souvisel(y) s koncentracemi lipidů, protože nebyly zjištěny žádné rozdíly v počátečních hodnotách lipidů mezi skupinou pacientů, kteří podstoupili laserovou léčbu, a skupinou bez laserové léčby. ${ }^{231}$ Přestože měla tato zjištění četná omezení, ${ }^{232}$ zejména neprovedení retinální fotografie na počátku v hlavní studii ke stanovení rozsahu předchozí retinopatie, malé počty př́hod v hlavní studii i podstudii a také nedostatečně definovaný biologický mechanismus, mnoho důkazů podpořilo příznivou roli fenofibrátu, a to hlavně ve velmi časných, často asymptomatických stadiích této komplikace. ${ }^{233}$ Pro potvrzení těchto zjištění se očekávají závěry podstudie ACCORD-EYE, ve které se hodnotí účinky intenzivní kontroly glykemie, intenzivního snížení krevního tlaku a kombinace fenofibrátu a simvastatinu na prevenci a progresi diabetické retinopatie. ${ }^{234}$

\section{Tabulka 6 Souhrn klíčových účinků fenofibrátu na retinopa- tii v klinické studie FIELD ${ }^{231}$}

\section{Hlavní studie ( $n=9795$ )}

$\downarrow$ první laserové léčby (terciární cílový ukazatel)

- Celkově o 31 \% (4,9\% s placebem vs. 3,4 \% s fenofibrátem, ARR $1,5 \%, p=0,0002$ )

- Pro makulární edém o $31 \%$ (3,4 \% vs. 2,4\%, ARR 1,0\%, $p=0,002)$

- Pro proliferativní retinopatii o $30 \%$ (2,2\% vs. 1,5\%, ARR 0,7 \%, $p=0,015$

- Větší prínos ( $\downarrow$ o $39 \%$ ) u pacientů bez předchozí retinopatie ( $2,8 \%$ vs. $1,7 \%$, ARR $1,1 \%, p=0,0008)$

Oftalmologická podstudie $(\mathrm{n}=1012$ )

Dvoustupňová progrese retinopatie na stupnici ETDRS (primární cílový ukazatel)

- $\downarrow$ o $22 \%(12,3 \%$ vs. 9,6 \%, ARR $2,7 \%, p=0,19)$ u všech pacientů

- $\downarrow$ o $79 \%$ (14,6 \% vs. 3,1 \%, ARR 11,5\%, $p=0,004)$ u pacientů $s$ předchozí retinopatií

Složený sledovaný ukazatel*

- $\downarrow$ o $31 \%(16,1 \%$ vs. $11,1 \%$, ARR 5,0 \%, p=0,022) u všech pacientů

* Složený sledovaný ukazatel definovaný jako jakákoli dvoustupňová progrese retinopatie, makulární edém nebo laserová léčba ( $v$ jednom oku); ETDRS - kritéria Early Treatment Diabetic Retinopathy Study.

Údaje jsou dány jako snížení relativního rizika (\% přihod) a snižení absolutního rizika (ARR).

\section{Diabetická neuropatie a amputace}

Klinické studie ukazují, že léčba modifikující lipidy může mít příznivé účinky na neurovaskulární funkci a diabetickou neuropatii. ${ }^{235-238}$ Předběžné observační údaje na základě longitudinální podskupiny 531 pacientů s diabetes mellitus 2. typu v klinické studii Fremantle Diabetes Study prokázaly, že použití statinu (HR 0,65; 95\% CI 0,46-0,93) nebo použití fibrátu (HR 0,52; 95\% CI 0,27-0,98) bylo významnou inverzní determinantou vzniku diabetické neuropatie $(p<0,05) .{ }^{239}$ Avšak v klinické studii STENO-2 bylo prokázáno, že intenzivní multifaktoriální intervence (včetně častého použití statinů) nedokázala zabránit vzniku ani progresi periferní neuropatie. ${ }^{13}$ Celkově jsou klinické údaje omezené. Použití suplementace $\omega$-3 mastnými kyselinami (EPA $1800 \mathrm{mg} / \mathrm{den}$ po dobu 48 týdnů) mělo příznivé účinky na diabetickou periferní neuropatii hodnocenou klinicky a pomocí percepčního prahu vnímání vibrací $\mathrm{v}$ dolních končetinách. ${ }^{240} \mathrm{~V}$ klinické studii FIELD bylo rovněž prokázáno, že fenofibrát snížil počet netraumatických amputací dolních končetin (předem definovaný terciární cílový ukazatel) oproti placebu $(38 \% ; p=0,011) .{ }^{241}$

\section{Řešení problému: výzva ke snížení reziduálního vaskulárního rizika}

Toto doporučení zdůrazňuje aterogenní dyslipidemii jako klíčový faktor spojený s reziduálním makrovaskulárním rizikem pacientů s dyslipidemií, včetně jedinců, kteří jsou léčeni pro vysokou koncentraci LDL cholesterolu a pro diabetes mellitus v souladu se současnými standardy péče. Aterogenní dyslipidemie se také podílí na patogenezi mikrovaskulárního reziduálního rizika diabetiků.

Iniciativa $\mathrm{R}^{3} \mathrm{i}$ zdůrazňuje, že $\mathrm{v}$ boji s hrozbami, které představují globální epidemie obezity, metabolický syndrom a diabetes mellitus 2. typu, je nutná edukace a komunikace, aby se zvýšilo povědomí o rozsahu a důležitosti aterogenní dyslipidemie $\mathrm{v}$ rámci reziduálního vaskulárního rizika. Modifikace životního stylu je důležitým, účinným a nedostatečně využívaným prvním krokem ke snížení tohoto rizika. Nezbytná bude pravděpodobně také intervence prostřednictvím farmakoterapie zaměřená na dosažení cílových hodnot všech lipidů (tabulka 7). Rozhodující informace týkající se použití kombinované léčby modifikující

Tabulka 7 Doporučení iniciativy $R^{3} i$ ke zlepšení vedení léčby reziduálního vaskulárního rizika

- Jako první krok začněte s úpravou životního stylu.

- Zlepšete cílové hodnoty lipidů, je-li to nutné. Užitečné může být přidání fibrátu, niacinu nebo $\omega-3$ mastných kyselin k léčbě statiny. Avšak pro porovnání těchto kombinací se statiny v monoterapii je nutné provedení dalších klinických studií.

- Normalizujte hodnoty glykovaného hemoglobinu $\left(\mathrm{HbA}_{1 \mathrm{c}}\right)$ a krevního tlaku.

- Intervenci prostřednictvím úpravy životního stylu a farmakoterapie zahajte co nejdřive na začátku choroby. 
lipidy poskytnou tři hlavní klinické studie - ACCORD, AIMHIGH a HPS2-THRIVE.

\section{Prohlášení o střetu zájmů}

J.-C. F. obdržel honoráře za členství v poradním výboru společnosti Solvay a honoráře za členství ve výboru přednášejících/práci konzultanta ve společnostech Solvay, AstraZeneca, Sanofi-Aventis, Kowa Company Ltd. Spoluzakladatel a předseda dozorčí rady společnosti Genfit.

F. M. S. obdržel prostředky na výzkum od ISIS a honoráře za konzultační činnost od společností Abbott, Aegerion, AstraZeneca, Genzyme, ISIS, Lilly, Lipid Sciences, Merck a Solvay. Obdržel honoráře za přednášky od společností WebMD, Abbott a Solvay. Je akcionářem Lipid Science.

M. P. H. působí v poradním panelu anebo obdržel honoráře či vědecké nebo cestovní granty od společností AstraZeneca, Bayer, Covance, Danone, Fournier, E Lilly, Solvay Pharma, GSK, LifeScan, Lipha, Medtronic-Minimed, Menarini, MSD, MSH, NovoNordisk, Nycomed, Pfizer, Roche, Sanofi-Aventis, Servier a Solvay. Solvay.

G. A. obdržel honorář za členství v poradním výboru od společnosti

W. V. B. obdržel výzkumné granty od společností AstraZeneca, Abbott a Lilly a honoráře za přednášky nebo konzultace od společností AstraZeneca, Abbott, Amgen, Glaxo SmithKline, Lilly, Merck, Merck-Schering Plough, Pfizer, Sanofi-Aventis a Solvay.

M. J. C. získal finance na výzkum od společností Merck, Pfizer a AstraZeneca a stejné společnosti sponzorovaly jeho prezentace na edukačních konferencích.

P. M. D. získal honoráře za členství v poradním výboru společností Pfizer, AstraZeneca, Takeda a Solvay a výzkumné granty od společnosti Eli Lilly.

H. N. G. získal honoráře za přednáškovou nebo konzultační činnost od společností Merck, Schering Plough, Astra Zeneca, Pfizer, Takeda, Reliant, Glaxo SmithKline, ISIS, Sanofi-Aventis a prostředky na výzkum od společností ISIS, Takeda, Sanofi-Aventis a Reliant.

J.-M. L. obdržel honoráře od společností AstraZeneca, MSD, Schering Plough, Novartis, Pfizer a Solvay.

N. M. získal výzkumné granty od společností Glaxo SmithKline, Takeda, Boehringer Ingelheim, Novartis, MSD a honoráře za členství v poradním výboru společností Glaxo SmithKline, Boehringer Ingelheim, NovoNordisk, MSD, Sankyo a za přednášky od společností Glaxo SmithKline, Takeda, Boehringer Ingelheim, BerlinChemie a MSD.

J. P. obdržel honoráře za konzultace od společností Dainippon Sumitomo America, Inc., Glaxo SmithKline, NovoNordisk, ONO Pharmaceuticals, Sanofi-Aventis a Takeda a za přednášky od společnosti Takeda.

Z. R. získal honoráŕe od společností MSD, Merck, Schering-Plough, GSK, Pfizer, Novartis, Solvay, Krka a Menarini.

R. S. R. získal finance od společnosti Abbott Laboratories Inc., Anthera, Inc. a AstraZeneca Inc. (výzkumný grant) a působil ve výboru před nášejících a dostává honoráře od společností Abbott a AstraZeneca, Inc. Má spoluvlastnický podíl a působí jako konzultant/člen poradního výboru v LipoScience.

B. S. obdržel honoráře za přednášky od společnosti Solvay.

R. S. získal výzkumné granty od společností Fournier Philippines, Pfizer Philippines a Takeda Philippines a honoráře za přednášky od společností MSD, Novartis, Pfizer, Therapharma, Sanofi-Aventis a Solvay.

A. Z. obdržel honoráře za přednášky od společností Solvay a AstraZeneca.

P. Z. obdržel honoráře od společností Bayer, Bristol-Myers Squibb, Glaxo SmithKline, Sanofi-Aventis, Solvay, Fournier, Novartis, Lilly a Merck Serono.

R. C., P. F., T. K., J. S. a C. W. nemají na věci finanční zájem.

Překlad vyhotovila agentura DynamicConcepts TCM, s.r.o.

\section{Literatura}

1. Zimmet P, Alberti KG, Shaw J. Global and societal implications of the diabetes epidemic. Nature 2001;414:782-787.

2. O'Flaherty M, Ford E, Allender S, et al. Conorary heart disease trends in England and Wales from 1984 to 2004; concealed levelling of mortality rates among young adults. Heart 2008;94:178-181.

3. Ford ES, Capewell S. Coronary heart disease mortality among young adults in the US from 1980 through 2002: concealed leveling of mortality rates. J Am Coll Cardiol 2007;50:2128-2132

4. Cardiovascular disease statistics. American Heart Association, http://www. americanheart.org/present.jhtml?identifier $=4478$.
5. European Heart Network. European cardiovascular disease statistics, 2008, Brussels. http://www.ehnheart.org (statistics).

6. National Cholesterol Education Program (NCEP) Expert Panel on Detection, Evaluation, and Treatment of High Blood Cholesterol in Adults (Adult Treatment Panel III). Third Report of the National Cholesterol Education Program (NCEP) Expert Panel on Detection, Evaluation, and Treatment of High Blood Cholesterol in Adults (Adult Treatment Panel III). Final report. Circulation 2002;106:3143-3421.

7. American Diabetes Association. Standards of medical care in diabetes - 2008. Diabetes Care 2008;31(suppl 1):S12-S54.

8. Smith SC Jr, Allen J, Blair SN, et al. AHA/ACC guidelines for secondary prevention for patients with coronary and other atherosclerotic vascular disease: 2006 update: endorsed by the National Heart, Lung, and Blood Institute. Circulation 2006;113:2363-2372.

9. Buse JB, Ginsberg HN, Bakris GL, et al., American Diabetes Association. Primary prevention of cardiovascular diseases in people with diabetes mellitus. A Scientific Statement from the American Heart Association and the American Diabetes Association. Circulation 2007;115:114-126.

10. Fourth Joint Task Force of the European Society of Cardiology and Other Societies on Cardiovascular Disease Prevention in Clinical Practice (constituted by representatives of nine societies and by invited experts), Graham I, Atar D, Borch-Johnsen K, et al. European guidelines on cardiovascular disease prevention in clinical practice: executive summary. Eur Heart J 2007;2375-2414.

11. Rydén L, Standl E, Bartnik M, et al., Task Force on Diabetes and Cardiovascular Diseases of the European Society of Cardiology (ESC): European Association for the Study of Diabetes (EASD). Guidelines on diabetes, pre-diabetes, and cardiovascular disease: executive summary. The Task Force on Diabetes and Cardiovascular Diseases of the European Society of Cardiology (ESC) and of the European Association for the Study of Diabetes (EASD). Eur Heart J 2007;28:88-136.

12. Gaede $P$, Vedel $P$, Larsen N, et al. Multifactorial intervention and cardiovascular disease in patients with type 2 diabetes. N Engl J Med 2003;348:383-393.

13. Gaede $\mathrm{P}$, Lund-Andersen $\mathrm{H}$, Parving $\mathrm{HH}$, Pedersen $\mathrm{O}$. Effect of a multifactorial intervention on mortality in type 2 diabetes. N Engl J Med 2008;358: 580-591.

14. Baigent C, Keech A, Kearney PM, et al., Cholesterol Treatment Trialists' (CTT) Collaborators. Efficacy and safety of cholesterol-lowering treatment: prospective meta-analysis of data from 90,056 participants in 14 randomised trial of statins. Lancet 2005;366:1267-1278.

15. Cholesterol Treatment Trialists' (CTT) Collaborators, Kearney PM, Blackwell PM, Collins R, et al. Efficacy of cholesterol-lowering therapy in 18,686 people with diabetes in 14 randomised trial of statins: a meta-analysis. Lancet 2008;371:117-125.

16. LaRosa JC, Grundy SM, Waters DD, et al.; Treating to New Targets (TNT) Investigators. Intensive lipid lowering with atorvastatin in patients with stable coronary disease. N Engl J Med 2005;352:1425-1435.

17. Cannon $\mathrm{CP}$, Braunwald $\mathrm{E}, \mathrm{McCabe} \mathrm{CH}$, et al., Pravastatin or Atorvastatin Evaluation and Infection Therapy-Thrombolysis in Myocardial Infarction-22 Investigators. Intensive versus moderate lipid lowering with statins after acute coronary syndromes. N Engl J Med 2004;350:1495-1504.

18. Yusuf S, Hawken S, Ounpuu S, et al.; INTERHEART Study Investigators. Effect of potentially modifiable risk factors associated with myocardial infarction in 52 countries (the INTERHEART study): case-control study. Lancet 2004; 364:937-952

19. Austin MA, King MC, Vranizan KM, Krauss RM. Atherogenic lipoprotein phenotype. A proposed genetic marker for coronary heart disease risk. Circulation 1990;82:495-506.

20. Ninomiya JK, L'Italien G, Criqui MH, et al. Association of the metabolic syndrome with history of myocardial infarction and stroke in the Third National Health and Nutrition Examination Survey. Circulation 2004;109: 42-46.

21. Assmann G, Schulte $H$, Cullen P, Seedorf U. Assessing risk of myocardial infarction and stroke: new data from the Prospective Cardiovascular Münster (PROCAM) study. Eur J Clin Invest 2007;37:925-932.

22. Assmann G, Schulte H, Seedorf U. Cardiovascular risk assessment in the metabolic syndrome. Results from the Prospective Cardiovascular Münster (PROCAM) study. Int J Obes 2008;32:S11-S16.

23. Sarwar N, Danesh J, Eiriksdottir G, et al. Triglycerides and the risk of coronary heart disease: 10,158 incident cases among 262, 525 participants in 29 Western prospective studies. Circulation 2007;115:450-458. 
24. Bansal S, Buring JE, Rifai N, et al. Fasting compared with nonfasting triglycerides and risk of cardiovascular events in women. JAMA 2007;298: 309-316.

25. Nordestgaard BG, Benn M, Schnohr P, Tybjaerg-Hansen A. Nonfasting triglycerides and risk of myocardial infarction, ischemic heart disease, and death in men and women. JAMA 2007;298:299-308.

26. Assmann G. Dyslipdaemia and global cardiovascular risk: clinical issues. Eur Heart J Suppl 2006;8(suppl F):F40-F46.

27. Sniderman A, Vu H, Cianflone K. Effect of moderate hypertriglyceridemia on the relation of plasma total and LDL apo B levels. Atherosclerosis 1991;89:109-116.

28. St-Pierre AC, Cantin B, Dagenais GR, et al. Low-density lipoprotein subfractions and the long-term risk of ischemic heart disease in men: 13-year follow-up data from the Québec Cardiovascular Study. Arterioscler Thromb Vasc Biol 2005;25:533-539.

29. Walldius G, Jungner I, Holme I, et al. High apolipoprotein B, low apolipoprotein $\mathrm{A}-\mathrm{I}$, and improvement in the prediction of fatal myocardial infarction (AMORIS study): a prospective study. Lancet 2001;358:2026-2033.

30. Shai I, Rimm EB, Hankinson SE, et al. Multivariate assessment of lipid parameters as predictors of coronary heart disease among postmenopausal women: potential implications for clinical guidelines. Circulation 2004;110:2824-2830.

31. Jiang R, Schulze MB, Li T, et al. Non-HDL cholesterol and apolipoprotein $B$ predict cardiovascular disease events among men with type 2 diabetes. Diabetes Care 2004;27:1991-1997.

32. Pischon T, Girman CJ, Sacks FM, et al. Non-high-density lipoprotein cholesterol and apolipoprotein $\mathrm{B}$ in the prediction of coronary heart disease in men. Circulation 2005;112: 3375-3383.

33. Gotto AM Jr, Whitney E, Stein EA, et al. Relation between baseline and on-treatment lipid parameters and first acute major coronary events in the Air Force/Texas Coronary Atherosclerosis Prevention Study (AFCAPS/ TexCAPS). Circulation 2000;101:477-484.

34. Simes RJ, Marschner IC, Hunt D, et al.; LIPID Investigators. Relationship between lipid levels and clinical outcomes in the Longterm Intervention with Pravastatin in Ischemic Disease (LIPID) Trial: to what extent is the reduction in coronary events with pravastatin explained by on-study lipid levels? Circulation 2002;105:1162-1169.

35. Van Lennep JE, Westerveld HT, Van Lennep HW, et al. Apolipoprotein concentrations during treatment and recurrent coronary artery disease events. Arterioscler Thromb Vasc Biol 2000;20:2408-2513.

36. Kathiresan S, Otvos JD, Sullivan LM, et al. Increased small low-density lipoprotein particle number. A prominent feature of the metabolic syndrome in the Framingham Heart Study. Circulation 2006;113:20-29.

37. Sacks FM, Campos H. Clinical review 163: Cardiovascular endocrinology: Low-density lipoprotein size and cardiovascular disease: a reappraisal. J Clin Endocrinol Metab 2003;88:4525-4532.

38. Jungner I, Sniderman AD, Furberg C, et al. Does low-density lipoprotein size add to atherogenic particle number in predicting the risk of fatal myocardial infarction? Am J Cardiol 2006;97:943-946.

39. Brunzell JD, Davidson M, Furberg DC, et al.; American Diabetes Association, American College of Cardiology Foundation. Lipoprotein management in patients with cardiometabolic risk: consensus statement from the American Diabetes Association and the American College of Cardiology Foundation. Diabetes Care 2008;31:811-822.

40. Alaupovic P, MackW, Knight-Gibson C, Hodis HN. The role of triglyceride-rich lipoprotein families in the progression of atherosclerotic lesions as determined by sequential coronary angiography from a controlled clinical trial. Arterioscler Thromb Vasc Biol 1997;17:715-722.

41. Sacks FM, Alaupovic P, Moye LA, et al. VLDL, apolipoproteins B, CIII, and E and risk of recurrent coronary events in the Cholesterol and Recurrent Events (CARE) trial. Circulation 2000;102:1886-1892.

42. Lee Sj, Campos H, Moye LA, Sacks FM. LDL containing apolipoprotein CIII is an independent risk factor for coronary events in diabetic patients. Arterioscler Thromb Vasc Biol 2003;23:853-858.

43. Chivot L, Mainard F, Bigot E, et al. Logistic discriminant analysis of lipids and apolipoproteins in a population of coronary bypass patients and the significance of apolipoproteins CIII and E. Atherosclerosis 1990;82:205-211.

44. Luc G, Fievet C, Arveiler D, et al. Apolipoproteins CIII and E in apoB and non-apoB-containing lipoproteins in two populations at contrasting risk for myocardial infarction: the ECTIM study. Etude Cas Témoins sur 'Infarctus du Myocarde. J Lipid Res 1996;37:508-517.
45. Blankenhorn DH, Alaupovic P, Wickham E, et al. Prediction of angiographic change in native human coronary arteries and aortocoronary bypass grafts. Circulation 1990;81:470-476.

46. Hodis HN, Mack WJ, Azen JP, et al. Triglyceride- and cholesterol-rich lipoproteins have a differential effect on mild/moderate and severe lesion progression as assessed by quantitative coronary angiography in a controlled trial of lovastatin. Circulation 1994;90:42-49.

47. Olivieri O, Bassi A, Stranieri C, et al. Apolipoprotein C-III, metabolic syndrome, and risk of coronary artery disease. J Lipid Res 2003;44:2374-2381.

48. Onat A, Hergenc G, Sansoy V, et al. Apolipoprotein C-III, a strong discriminant of coronary risk in men and a determinant of the metabolic syndrome in both genders. Atherosclerosis 2003;168:81-89.

49. Cohn JS, Patterson BW, Uffleman KD, et al. Rate of production of plasma and very-low-density lipoprotein (VLDL) apolipoprotein CIII is strongly related to the concentration and level of production of VLDL-triglyceride in male subjects with different body weights and levels of insulin sensitivity. J Clin Endocrinol Metab 2004;89:3949-3955.

50. Campos H, Perlov D, Khoo C, Sacks FM. Distinct patterns of lipoproteins with apoB defined by presence of apoE or apoCIII in hypercholesterolemia and hypertriglyceridemia. J Lipid Res 2001;42:1239-1249.

51. Juntii-Berggren L, Refai E, Appelskog I, et al. Apolipoprotein CIII promotes $\mathrm{Ca}^{2+}$-dependent beta cell death in type 1 diabetes. Proc Natl Acad Sci USA 2004;101:10090-10094.

52. Chen M, Breslow JL, Li W, Leff T. Transcriptional regulation of the apoC-III gene by insulin in diabetic mice: correlation with changes in plasma triglyceride levels. J Lipid Res 1994;35:1918-1924.

53. Klein RL, McHenry MB, Lok KH, et al.; DCCT/EDIC Research Group. Apolipoprotein CIII protein concentrations and gene polymorphisms in Type 1 diabetes: associations with microvascular disease complications in the DCCT/EDIC cohort. J Diabetes Complicatons 2005;19:18-25.

54. Kawakami A, Aikawa M, Libby P, et al. Apolipoprotein CIII in apolipoprotein $B$ lipoproteins enhances the adhesion of human monocystic cells to endothelial cells. Circulation 2006;113:691-700.

55. Kawakami A, Aikawa M, Alcaide P, et al. Apolipoprotein CIII induces expression of vascular cell adhesion molecule-1 in vascular endothelial cells and increases adhesion of monocytic cells. Circulation 2006;114:681-687.

56. Kawakami A, Aikawa M, Nitta N, et al. Apolipoprotein CIII-induced THP-1 cell adhesion to endothelial cells involves pertussis toxin-sensitive G-protein- and protein kinase C-alpha-mediated nuclear factor-kappaB activation. Arterioscler Thromb Vasc Biol 2007;27:219-225.

57. Birjmohun RS, Dallinga-Thie GM, Kuivenhoven JA, et al. Apolipoprotein A-II is inversely associated with risk of future coronary artery disease. Circulation 2007;116:2029-2035.

58. Stampfer MJ, Sacks FM, Salvini S, et al. A prospective study of cholesterol, apolipoproteins, and the risk of myocardial infarction. N Engl J Med 1991; 325:373-381.

59. Ballantyne CM, Olsson AG, Cook TJ, et al. Influence of low high-density lipoprotein cholesterol and elevated triglyceride on coronary heart disease events and response to simvastatin therapy in 4S. Circulation 2001;104: 3046-3051.

60. Barter PJ, Gotto AM, LaRosa JC, et al.; Treating to New Targets Investigators. HDL cholesterol, very low levels of LDL cholesterol, and cardiovascular events. N Engl J Med 2007;357:1301-1310.

61. Miller M, Cannon CP, Murphy SA, et al.; PROVE-IT TIMI 22 Investigators. Impact of triglyceride levels beyond low-density lipoprotein cholesterol after acute coronary syndrome in the PROVE-IT TIMI 22 trial. J Am Coll Cardiol 2008;51:724-730.

62. Jenkins AJ, Rowley KG, Lyons TJ, et al. Lipoproteins and diabetic microvascular complications. Curr Pharm Des 2004;10:3395-3418.

63. Chew EY, Klein ML, Ferris FL $3^{\text {rd }}$, et al. Association of elevated serum lipid levels with retinal hard exudate in diabetic retinopathy. Early Treatment Diabetic Retinopathy Study (ETDRS) Report 22. Arch Ophthalmol 1996;114: 1079-1084.

64. Ucgun NI, Yildirim Z, Kilic N, Gürsel E. The importance of serum lipids in exudative diabetic macular edema in type 2 diabetic patients. Ann NY Acad Sci 2007;1100:213-217.

65. Chowdhury TA, Hopkins D, Dodson PM, Vafidis GC. The role of serum lipids in exudative diabetic maculopathy: is there a place for lipid-lowering therapy? Eye 2002;16:689-693.

66. Davis MD, Fisher MR, Gangnon RE, et al. Risk factors for high-risk proliferative diabetic retinopathy and severe visual loss. Early Treatment Dia- 
betic Retinopathy Study Report 18. Invest Ophthalmol Vis Sci 1998 39:233-252.

67. Lyons TJ, Jenkins AJ, Zheng D, et al. Diabetic retinopathy and serum lipoprotein subclasses in the DCCT/EDIC cohort. Invest Ophthalmol Vis SC 2004;45:910-918.

68. Caramori ML, Fioretto P, Mauer M. The need for early predictors of diabetic nephropathy risk. Is albumin excretion rate sufficient? Diabetes 2000;49:1399-1408.

69. Retnakaran R, Cull CA, Thorne Kl, et al.; UKPDS Study Group. Risk factors for renal dysfunction in type 2 diabetes: UK Prospective Diabetes Study 74. Diabetes 2006;55:1832-1839.

70. Chaturvedi N, Fuller JH, Taskinen M-R, EURODIAB PCS Group. Differing associations of lipid and lipoprotein disturbances with the macrovascular and microvascular complications of type 1 diabetes. Diabetes Care 2001; 24:2071-2077.

71. Jenkins AJ, Lyons TJ, Zheng D, et al.; DCCT/EDIC Research Group. Lipoproteins in the DCCT/EDIC Research Group: associations with diabetic nephropathy. Kidney Int 2003;64:817-828.

72. Molitch ME, Rupp D, Carnethon M. Higher levels of HDL cholesterol are associated with a decreased likelihood of albuminuria in patients with long-standing type 1 diabetes. Diabetes Care 2006;29:78-82.

73. Tesfaye S, Chaturvedi N, Eaton SE, et al.; EURODIAB Prospective Complications Study Group. Vascular risk factors and diabetic neuropathy. N Eng J Med 2005;352:341-350.

74. Kempler P, Tesfaye S, Chaturvedi N, et al., EURODIAB IDDM Complications Study Group. Autonomic neuropathy is associated with increased cardio vascular risk factors: the EURODIAB IDDM Complications Study. Diabet Med 2002;19:900-909.

75. Delerive P, Fruchart JC, Staels B. Peroxisome proliferator-activated receptors in inflammation control. J Endocrinol 2001;169:453-459.

76. Fruchart JC, Duriez P, Staels B. Peroxisome proliferator-activated receptor-alpha activators regulate genes governing lipoprotein metabolism, vascular inflammation, and atherosclerosis. Curr Opin Lipidol 199;10: 245-247.

77. Pettersson C, Fogelstrand L, Rosengren B, et al. Increased lipolysis by secretory phospholipase A2 group V of lipoproteins in diabetic dyslipidemia. J Internal Med 2008;264:155-165.

78. Kontush A, Chapman MJ. Functionally defective high-density lipoprotein: a new therapeutic target at the crossroads of dyslipidaemia, inflammation, and atherosclerosis. Pharmacol Rev 2006;58:342-374.

79. De Souza JA, Vindis C, Hansel B, et al. Metabolic syndrome features small, apolipoprotein A-I-poor, triglyceride-rich HDL3 particles with defective anti-apoptotic activity. Atherosclerosis 2008;197:84-94.

80. Miller GJ, Martin JC, Mitropoulos KA, et al. Plasma factor VII is activated by postprandial triglyceridaemia, irrespective of dietary fat composition. Atherosclerosis 1991;86:163-171.

81. Silveria A, Karpe $F$, Johnsson $H$, et al. In vivo demonstration in humans that large postprandial triglyceride-rich lipoproteins activate coagulation factor VII through the intrinsic coagulation pathway. Arterioscler Thromb Vasc Biol 1996;16:1333-1339.

82. Maede TW, Mellows S, Brozovic M, et al. Heamostatic fiction and ischaemic heart disease: principal results of the Northwick Park Heart Study. Lancet 1986;2:533-537.

83. De Stavola BL, Meade TW. Long-term effects of hemostatic variables on fatal coronary heart disease: 30-year results from the first prospective Northwick Park Heart Study (NPHS-I). J Thromb Haemost 2007;5: $461-471$.

84. Juhan-Vague I, Morange $P$, Frere $C$, et al. The plasminogen activator in hibitor-1-675 4G/5G genotype influences the risk of myocardial infarction associated with elevated plasma proinsulin and insulin concentrations in men from Europe: the HIFMECH study. J Thromb Haemostas 2003;1: 2322-2329.

85. Asplund-Carlson A, Hamsten A, Wiman B, Carlson LA. Relationship between plasma plasminogen activator inhibitor-1 activity and VLDL triglyceride concentration, insulin levels and insulin sensitivity: studies in randomly selected normo- and hypertriglyceridaemic men. Diabetologia 1993;36: 817-825.

86. Dichtl W, Ares MP, Stollenwerk M, et al. In vivo stimulation of vascular plasminogen activator inhibitor-1 production by very low-density lipoprotein involves transcription factor binding to a VLDL-responsive element. Thromb Haemostas 2000;84:706-711.
87. American Heart Association Nutrition Committee, Lichtenstein AH, Appel LJ, Brands M, et al. Diet and lifestyle recommendations revision 2006: a scientific statement from the American Heart Association Nutrition Committee. Circulation 2006;114:82-96.

88. Trichopoulou A, Costacou T, Bamia C, Trichopoulous D. Adherence to a Mediterranean diet and survival in a Greek population. N Engl J Med 2003;348:2599-2608.

89. Trichopoulou A, Bamia C, Trichopoulous D. Mediterranean diet and survival among patients with coronary heart disease in Greece. Arch Intern Med 2005;165:929-935.

90. Giugliano D, Esposito K. Mediterranean diet and metabolic diseases. Curr Opin Lipidol 2008;19:63-68.

91. McKellar G, Morrison E, McEntegart A, et al. A pilot study of a Mediterranean-type diet intervention in female patients with rheumatoid arthritis living in areas of social deprivation in Glasgow. Ann Rheum Dis 2007;66: $1239-1243$.

92. Gao $X$, Chen $\mathrm{H}$, Fung TT, et al. Prospective study of dietary patterns and risk of Parkinson disease. Am J Clin Nutr 2007;86:1486-1494.

93. Scarmeas N, Luchsinger JA, Mayeux R, Stern Y. Mediterranean diet and Alzheimer disease mortality. Neurology 2007;69:1084-1093.

94. Trichopoulou A, Kouris-Blazos A, Wahlqvist ML, et al. Diet and overall survival in the elderly. BMJ 1995;311:1457-1460.

95. Esposito K, Marfella R, Ciotola M, et al. Effect of a Mediterranean-style diet on endothelial dysfunction and markers of vascular inflammation in the metabolic syndrome. JAMA 2004;292:1440-1446.

96. Appel LJ, Sacks FM, Carey VJ, et al.; OmniHeart Collaborative Research Group. Effects of protein, monosaturated fat, and carbohydrate intake on blood pressure and serum lipids: results of the OmnilHeart randomized trial. JAMA 2005;294:2455-2464.

97. Sacks FM, Svetkey LP, Vollmer WM, et al.; Dash-Sodium Collaborative Research Group. Effects on blood pressure of reduced dietary sodium and the Dietary Approaches to Stop Hypertension (DASH) diet. DASH-Sodium Collaborative Research Group. N Engl J Med 2001;344:3-10.

98. Parikh P, McDaniel MC, Ashen MD, et al. Diets and cardiovascular disease: an evidence-based assessment. J Am Coll Cardiol 2005;45: 1379-1387.

99. De Lorgeril M, Renaud S, Mamelle N, et al. Mediterranean alphalinolenic acid-rich diet in secondary prevention of coronary heart disease. Lancet 1994;343:1454-1459.

100. Gruppo Italiano per lo Studio della Sporavvivenza nell'Infarto miocardico. Dietary supplementation with $n-3$ polyunsaturated fatty acids and vitamin E after myocardial infarction: results of the GISSI-Prevenzione trial. Lancet 1999;354:447-455.

101. Marchioli R, Barzi F, Bomba E, et al.; GISSI-Prevenzione Investigators. Early protection against sudden death by $n-3$ polyunsaturated fatty acids after myocardial infarction: time course analysis of the results of the Gruppo Italiano per lo Studio della Sopravvivenza nell'Infarto miocardio (GISSI)-Prevenzione. Circulation 2002;105:1897-1903.

102. Sacks FM, Katan M. Randomised clinical trials on the effects of dietary fat and carbohydrate on plasma lipoproteins and cardiovascular disease. Am J Med 2002;113(suppl 9b):13S-24S.

103. Mensink RP, Zock PL, Kester AD, Katan MB. Effects of dietary fatty acids and carbohydrates on the ratio of serum total to HDL cholesterol and on serum lipids and apolipoproteins: a meta-analysis of 60 controlled trials. Am J Clin Nutr 2003;77:1146-1155

104. Garg A. High-monounsaturated fat diet for diabetic patients. Is it time to chase the current dietary recommendations? Diabetes Care 1994;17:242-246.

105. Covas MI, Nyyssonen K, Poulsen HE, et al., EUROLIVE Study Group. The effect of polyphenols in olive oil on heart disease risk factors: a randomized trial. Ann Intern Med 2006;145:333-341.

106. Laaksonen DE, Nyyssönen K, Niskanen L, et al. Prediction of cardiovascular mortality in middle-aged men by dietary and serum linoleic and polyunsaturated fatty acids. Arch Intern Med 2005;165:193-196.

107. Campos H, Baylin A, Willett WC. Alpha linolenic acid and risk of nofatal myocardial infarction. Circulation 2008;118:339-345.

108. Forsythe CE, Phinney SD, Fernandez ML, et al. Comparison of low fat and low carbohydrate diets on circulating fatty acid composition and markers of inflammation. Lipids 2008;43:65-77.

109. Bassuk SS, Manson JE. Epidemiological evidence for the role of physical activity in reducing risk of type 2 diabetes and cardiovascular disease. J Appl Physiol 2005;99:1193-1304. 
110. Jeon CY, Lokken RP, Hu FB, van Dam RM. Physial activity of moderate intensity and risk of type 2 diabetes. A systematic review. Diabetes Care 2007;30:744-752.

111. Trichopoulou A, Psaltopoulou T, Orfanos P, Trichopoulos D. Diet and physical activity in relation to overall mortality amongst adult diabetics in a general population cohort. J Intern Med 2006;259:583-591.

112. Weinstein AR, Sesso HD, Lee IM, et al. The joint effects of physical activity and body mass index on coronary heart disease risk in women. Arch Intern Med 2008;168:884-890.

113. DeFronzo RA, Sherwin RS, Kraemer N. Effect of physical training on insulin action in obesity. Diabetes 1987;36:1379-1385.

114. Thomas DE, Elliott EJ, Naughton GA. Exercise for type 2 diabetes mellitus. Cochrane Database System Rev 2006;3:CD002968.

115. Sigal RJ, Kenny GP, Boule NG, et al. Effects of aerobic training, resistence training, or both on glycemic control in type 2 diabetes: a randomized trial. Ann Intern Med 2007;147:357-369.

116. Kraus WE, Houmard JA, Duscha BD, et al. Effects of the amount and intensity of exercise on plasma lipoproteins. N Engl J Med 2002;347: 1483-1492.

117. Koclama S, Tanaka S, Saito K, et al. Effect of aerobic exercise training on serum levels of high-density lipoprotein cholesterol: a meta-analysis. Arch Intern Med 2007;167:999-1008.

118. Kelley GA, Kelley KS, Tran ZV. Exercise, lipids, and lipoproteins in older adults. A meta-analysis. Prev Cardiol 2005;8:206-214.

119. Kelley GA, Kelley KS. Aerobic exercise and lipids and lipoproteins in children and adolescents. A meta-analysis of randomized controlled trials. Atherosclerosis 2007;191:447-453.

120. Stewart KJ, Bacher AC, Turner K, et al. Exercise and risk factors associated with metabolic syndrome in older adults. Am J Prev Med 2005; 28:9-18.

121. Whelton SP, Chin A, Xin X, He J. Effect of aerobic exercise on blood pressure: a meta-analysis of randomized, controlled trials. Ann Intern Med 2002;136:493-503.

122. Wolff I, van Croonenborg JJ, Kemper HC, et al. The effect of exercise training programs on bone mass: a meta-analysis of published controlled trials in pre- and postmenopausal women. Osteoporos Int 1999;9:1-12.

123. Hassmen P, Koivula N, Uutela A. Physical exercise and psychological well-being: a population study in Finland. Prev Med 2000;30:17-25.

124. Duncan GE, Anton SD, Sydeman SJ, et al. Prescribing exercise at varied levels of intensity and frequency: a randomized trial. Arch Intern Med 2005;165:2362-2369.

125. Laaksonen DE, Lindstorm J, Lakka TA, et al.; Finnish Diabetes Prevention Study. Physical activity in the prevention of type 2 diabetes: the Finnish diabetes prevention study. Diabetes 2005;54:158-165.

126. Johnson JL, Slenz CA, Houmard JA, et al. Exercise training amount and intensity effects on metabolic syndrome (from Studies of a Targeted Risk Reduction Intervention through Defined Exercise). Am J Cardiol 2007;100: 1759-1766.

127. O'Keefe JH, Bybee KA, Lavie CJ. Alcohol and cardiovascular health: the razor-sharp double-edge sword. J Am Coll Cardiol 2007;50:1009-1014.

128. Ginsberg H, Olefsky J, Farquar J, Reaven G. Moderate etanol ingestion and plasma triglyceride levels. Ann Intern Med 1974;80:143-149.

129. Crouse JR, Grundy SM. Effects of alcohol on plasma lipoproteins and cholesterol and triglyceride metabolism in man. J Lipid Res 1984;25: 486-496.

130. Chiuve SE, McCullough ML, Sacks FM, Rimm EB. Healthy lifestyle factors in the primary prevention of coronary heart disease among men: benefits among users and nonusers of lipid-lowering and anti-hypertensive medications. Circulation 2006;114:160-167.

131. The Lipid Research Clinics Coronary Primary Prevention Trial results. I. Reduction in incidence of coronary heart disease. JAMA 1984;251: 351-364.

132. Rossebo AB, Perdersen TR, Borman $K$, et al. Intensive lipid lowering with simvastatin and ezetimibe in aortic stenosis. N Engl J Med 2008;359: 1343-1356.

133. Peto R, Emberson J, Landray M, et al. Analyse of cancer data from free ezetimibe trials. N Engl J Med 2008;359:1357-1366.

134. Drazen JM, D'Agostino RB, Ware JH, et al. Ezetimibe and cancer - an uncertain association. N Engl J Med 2008:359:1398-1399.

135. Pourcet B, Fruchart JC, Staels B, Glineur C. Selective PPAR modulators, dual and pan PPAR agonists: multimodal drugs for the treatment of type 2 diabetes and atherosclerosis. Expert Opin Emerg Drugs 2006;11: 379-401.

136. Frick MH, Elo O, Haapa K, et al. Helsinki Heart Study: primary prevention trial with gemfibrozil in middle-aged men with dyslipidemia. Safety of treatment, changes in risk factors, and incidence of coronary heart disease. N Engl J Med 1987;317:1237-1245.

137. Rubins HB, Robins SJ, Collins D, et al. Gemfibrozil for the secondary prevention of coronary heart disease in men with low levels of high-density lipoprotein cholesterol. Veterans Affairs High-Density Lipoprotein Cholesterol Intervention Trial Study Group. N Engl J Med 1999;341:410-418.

138. The Bezafibrate Infarction Prevention (BIP) study group. Secondary prevention by rating $\mathrm{HDL}$ cholesterol and reducing triglycerides in patients with coronary artery disease. The Bezafibrate Infarction Prevention (BIP) study. Circulation 2000;102:21-27.

139. Keech A, Simes RJ, Barter P, et al. The FIELD study investigators. Effects of long-term fenofibrate therapy on cardiovascular events in 9795 people with type 2 diabetes mellitus (the FIELD study): randomised controlled trial. Lancet 2005;366:1849-1861.

140. Gross B, Staels B. PPAR agonists: multimodal drugs for the treatment of type-2 diabetes. Best Pract Res Clin Endocrinol Metab 2007;21:687-710.

141. Staels B, Fruchart JC. Therapeutic roles of peroxisome proliferator-activated receptor agonists. Diabetes 2005;54:2460-2470.

142. Ooi TC, Cousins M, Ooi DS, et al. Effect of fibrates on postprandial remnant-like particles in patients with combined hyperlipidemia. Atherosclerosis 2004;172:375-382.

143. Rosenson RS, Wolff DA, Huskin AL, et al. Fenofibrate therapy ameliorates fasting and postprandial lipoproteinemia, oxidative stress, and the inflammatory response in subjects with hypertriglyceridemia and the metabolic syndrome. Diabetes Care 2007;30:1945-1951.

144. Duez H, Lefebvre B, Poulain $P$, et al. Regulation of human apo A-I by gemfibrozil and fenofibrate through selective peroxisome proliferator-actived receptor alpha modulation. Arterioscler Thromb Vasc Biol 2005; 25:585-591.

145. Chapman MJ. Fibrates in 2003. Therapeutic action in atherogenic dyslipidemia and future perspectives. Atherosclerosis 2003;171:1-13.

146. Ooi TC, Heinonen T, Alaupovic $P$, et al. Efficacy and safety of a new hydroxymethylglutaryl-coenzyme $A$ reductase inhibitor, atorvastatin, in patients with combined hyperlipidemia. Comparison with fenofibrate. Arterioscler Thromb Vasc Biol 1997;17:1793-1799.

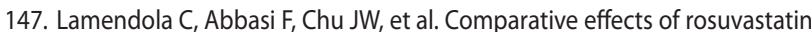
and gemfibrozil on glukose, insulin, and lipid metabolism in insulin-resistant, nondiabetic patients with combined dyslipidemia. Am J Cardiol 2005;95:189-193.

148. Wagner JA, Larson PJ, Weiss S, et al. Individual and combined effects of peroxisome proliferator-activated receptor and (gamma) agonists, fenofibrate and rosiglitazone, on biomarkers of lipid and glucose metabolism in healthy nondiabetic volunteers. J Clin Pharmacol 2005;45:504-513.

149. Davidson MH, Bays HE, Stein E, et al.; TRIMS Investigators. Effects of fenofibrate on atherogenic dyslipidemia in hypertriglyceridemic subjects. Clin Cardiol 2006;29:268-273.

150. Rosenson RS, Huskin AL, Wolff DA, et al. Fenofibrate reduces fasting and postprandial inflammatory responses among hypertriglyceridemia patients with the metabolic syndrome. Atherosclerosis 2008;198:381-388.

151. Coronary Drug Project Research Group. Clofibrate and niacin in coronary heart disease. JAMA 1975;231:360-381.

152. Committee of Principal Investigators. A cooperative trial in the prevention of ischemic heart disease using clofibrate. Br Heart J 1978;40:1069-1118.

153. Tenkanen $L$, Mantarri M, Manninen V. Some coronary risk factors related to the insulin resistence syndrome and treatment with gemfibrozil: experience from the Helsinki Heart Study. Circulation 1995;92:1779-1785.

154. Rubins HB, Robins SJ, Collins D, et al. Diabetes, plasma insulin, and cardiovascular disease: subgroup analysis from the Department of Veterans Affairs high-density lipoprotein intervention trial (VA-HIT). Arch Intern Med 2002;162:2597-2604.

155. Tenebaum A, Motro M, Fisman EZ, et al. Bezafibrate for the secondary prevention of myocardial infarction in patients with metabolic syndrome. Arch Intern Med 2005;165:1154-1160.

156. Scott R, d'Emden M, Best J, et al.; on behalf of the FIELD Investigators. Features of metabolic syndrome identify individuals with type 2 diabetes mellitus at high risk for cardiovascular events and greater absolute benefits of fenofibrate. Circulation 2007;116:II_838. Abstract 3691. 
157. Arthur JB, Ashby DWR, Bremer C, et al. Trial of clofibrate in the treatment of ischaemic heart disease. Five-year study by a group of physicians of the Newcastle upon Tyne region. BMJ 1971;4:767-775.

158. Research Committee of the Scottish Society of Physicians. Ischaemic heart disease: a secondary prevention trial using clofibrate. Report by a Research Committee of the Scottish Society of Physicians. BMJ 1971;4:775-784.

159. Keech A, Simes J, Barter P, et al.; FIELD Management Committee. Correction to the FIELD study report. Lancet 2006;368:1415 (letter).

160. Grundy SM, Vega GL, Yuan Z, et al. Effectiveness and tolerability of simvastatin plus fenofibrate for combined hyperlipidemia (the SAFARI trial). Am J Cardiol 2005;95:462-468.

161. Athyros VG, Papageorgiou AA, Athyrou VV, et al. Atorvastatin and micronized fenofibrate alone and in combination in type 2 diabetes with combined hyperlipidemia. Diabetes Care 2002;25:1198-1202.

162. Alsheikh-Ali AA, Kuvin JT, Karas RH. Risk of adverse events with fibrates. Am J Cardiol 2004;94:935-938.

163. Rosenson RS. Current overview of statin-induced myopathy. Am J Med 2004;116:408-416.

164. Gaist D, Rodriguez LA, Huerta C, et al. Lipid-lowering drugs and risk of myopathy: a population-based follow-up study. Epidemiology 2001;12:565-569.

165. Jones $\mathrm{PH}$, Davidson $\mathrm{MH}$. Reporting rate of rhabdomyolysis with fenofibrate + statin versus gemfibrozil + any statin. Am J Cardiol 2005;95:120-122.

166. Prueksaritanont T, Tang C, Qui Y, et al. Effects of fibrates on metabolism of statins in human hepatocytes. Drug Metab Dispos 2002;30:1280-1287.

167. Davidson MH, Armani A, McKenney JM, Jacobson TA. Safety considerations with fibrate therapy. Am J Cardiol 2007;99(suppl. 6A):3C-18C.

168. Ansquer JC, Foucher C, Rattier S, et al.; DAIS Investigators. Fenofibrate reduces progression to microalbuminuria over 3 years in a placebo-controlled study in type 2 diabetes: results from the Diabetes Atherosclerosis Intervention Study (DAIS). Am J Kidney Dis 2005;45:485-493.

169. Ginsberg HN, Bonds D, Lovato LC, et al.; ACCORD Study Group. Evolution of the lipid trial protocol of the Action to Control Cardiovascular Risk in Diabetes (ACCORD) trial. Am J Cardiol 2007;99(suppl. 12A):56i-76i.

170. Morgan JM, Capuzzi DM, Guyton JR, et al. Treatment effect of Niaspan, a controlled-release niacin, in patients with hypercholesterolemia: a placebo-controlled trial. J Cardiovasc Pharmacol Ther 1996;1:195-202.

171. Goldberg A, Alagona P Jr, Capuzzi DM, et al. Multiple-dose efficacy and safety of an extended-release form of niacin in the management of hyperlipidemia. Am J Cardiol 2000;85:1100-1105.

172. Luc G, Bard JM, Arveiler D, et al.; PRIME Study Group. Lipoprotein(a) as a predictor of coronary heart disease: the PRIME study. Atheroclerosis 2002;163:377-384.

173. Von Eckardstein A, Schulte H, Cullen P, Assmann G. Lipoprotein(a) further increases the risk of coronary events in men with high global cardiovascular risk. J Am Cardiol 2001;37:434-439.

174. Danesh J, Collins R, Peto R. Lipoprotein(a) and coronary heart disease. Meta-analysis of prospective studies. Circulation 2000;102:1082-1085.

175. McCormack PL, Keating GM. Prolonged-release nicotinic acid. A review of its use in the treatment of dyslipidaemia. Drugs 2005;65:2719-2740.

176. Morgan JM, Capuzzi DM, Baksh RI, et al. Effects of extended-release niacin on lipoprotein subclass distribution. Am J Cardiol 2003;91:1432-1436.

177. Pan J, Lin M, Kesala RL, et al. Niacin treatment of the atherogenic lipid profile and Lp(a) in diabetes. Diabetes Obes Metab 2002;4:255-261.

178. Karpe F, Frayn KN. The nicotinic acid receptor - a new mechanism for an old drug. Lancet 2004;363:1892-1894.

179. Soudijn W, van Wijngaarden I, ljzerman AP. Nicotinic acid receptor subtypes and their ligands. Med Res Rev 2007;27:417-433.

180. Wang W, Basinger A, Neese RA, et al. Effect of nicotinic acid administration on hepatic very low density lipoprotein-triglyceride production. Am J Physiol Endocrinol Metab 2001;280:E540-E547.

181. Kamanna VS, Kashyap ML. Mechanism of action of niacin on lipoprotein metabolism. Curr Atheroscler Rep 2000;2:36-46.

182. Stepherd J, Packard CJ, Patsch JR, et al. Effect of nicotinic acid therapy on plasma high density lipoprotein subfraction distribution and composition and on apolipoprotein A metabolism. J Clin Invest 1979;63:858-867.

183. Hernandez M, Wright SD, Cai TQ. Critical role of cholesterol ester transfer protein in nicotinic acid-mediated HDL elevation in mice. Biochem Biophys Res Commun 2007;355:1075-1080.

184. Rosenson RS. Antiatherothrombotic effects of nicotinic acid. Atherosclerosis 2003;171:87-96.
185. Pastemark RC, Brown LE, Stone PH, et al. Effect of combination therapy with lipid-reducing drugs in patients with coronary heart disease and 'normal' cholesterol levels. A randomized, placebo-controlled trial. Harvard Atherosclerosis Reversibility Project (HARP) Study Group. Ann Intern Med 1996;125:529-540.

186. McKenney JM, Jones PH, Bays HE, et al. Comparative effects on lipid levels of combination therapy with a statin and extended-release niacin or ezetimibe versus a statin alone (the COMPELL study). Atherosclerosis 2007;192:432-437.

187. Canner PL, Berge KG, Wenger NK, et al. Fifteen year mortality in Coronary Drug Project patients: long-term benefit with niacin. J Am Coll Cardiol 1986;8:1245-1255.

188. Canner PL, Furberg CD, Terrin ML, McGovern ME. Benefits of niacin by glycemic status in patients with healed myocardial infarction (from the Coronary Drug Project). Am J Cardiol 2005;95:254-257.

189. Brown G, Albers JJ, Fisher LD, et al. Regression of coronary artery disease as a result of intensive lipid-lowering therapy in men with high levels of apolipoprotein B. N Engl J Med 1990;323:1289-1298.

190. Brown BG, Zhao XQ, Chait A, et al. Simvastatin and niacin, antioxidant vitamins, or the combination for the prevention of coronary disease. N Engl J Med 2001;345:1583-1592.

191. Brown G. Expert commentary: niacin safety. Am J Cardiol 2007;99(suppl $6 \mathrm{~A}): 32 \mathrm{C}-34 \mathrm{C}$.

192. Guyton JR, Bays HE. Safety considerations with niacin therapy. Am J Cardiol 2007;99(suppl 6A):22C-31C.

193. Lai E, De Lepeleire I, Crumley TM, et al. Suppression of niacin-induced vasodilation with an antagonist to prostaglandin D2 receptor subtype 1. Clin Pharmacol Ther 2007;81:849-857.

194. Maccubbin D, Sirah W, Betteridge A. Lipid-altering efficacy and tolerability profile of extended release niacin/laropiprant in patients with primary hypercholesterolemia or mixed hyperlipidemia. Eur Heart J 2007;28 (abstract suppl):108. Abstract P715.

195. Grundy SM, Vega GL, McGovern ME, et al. Efficacy, safety, and tolerability of once-daily niacin for the treatment of dyslipidemia associated with type 2 diabetes: results of the Assessment of Diabetes Control and Evaluation of the Efficacy of Niaspan Trial. Arch Intern Med 2002;162:1568-1576.

196. Ginsberg HN, Niacin in the metabolic syndrome: more risk than benefit? Nat Clin Pract Endocrinol Metab 2006;2:300-331.

197. Clinical Trial: AIM HIGH: Niacin plus statin to prevent vascular events. www.clinicaltrials.gov.ct/show/NCT00120289.

198. Treatment of HDL to reduce the incidence of vascular events. HPs2-THRIVE. www.clinicaltrialsgov.ct/show/NCT00461.

199. Harris WS, Connor WE, Alam N, Illingworth DR. Reduction of postprandial triglyceridemia in humans by dietary n-3 fatty acids. J Lipid Res 1988;29: $1451-1460$.

200. Montori VM, Farmer A, Wollan PC, Dinheen SF. Fish oil supplementation in type 2 diabetes: a quantitative systemic review. Diabetes Care 2000;23: $1407-1415$.

201. Sethi S, Ziouzenkova O, Ni H, et al. Oxidized omega-3 fatty acids in fish oil inhibit leukocyte-endothelial interactions through activation of PPAR alpha. Blood 2002;100:1340-1346.

202. Kris-Etherton PM, Harris WS, Appel LJ; American Heart Association, Nutrition Committee. Fish consumption, fish oil, omega-3 fatty acids, and cardiovascular disease. Circulation 2002;106:2747-2757.

203. Secondary prevention in primary and secondary care for patients following a myocardial infarction. Clinical guideline. May 2007. National Institute for Health and Clinical Excellence. http://www.nice.org.uk/nicemedia/pdf/ CG48NICEGuidance.pdf

204. Nambi V, Ballantyne CM. Combination therapy with statins and omega-3 fatty acids. Am J Cardiol 2006;98(suppl 4A):34i-38i.

205. Leaf A, Kang JX, Xiao YF. Omega-3 fatty acids and ventricular arrhythmias. World Rev Nutr Diet 2005;94:129-138.

206. Leaf A. Omega-3 fatty acids and prevention of arrhythmias. Curr Opin Lipidol 2007;18:31-34.

207. Yokoyama M, Origasa $H$, Matsuzaki M, et al.; Japan EPA Lipid Intervention Study (JELIS) Investigators. Effects of eicosapentaenoic acid on major coronary events in hypercholesterolaemic patients (JELIS): a randomised open-label, blinded endpoint analysis. Lancet 2007;369:1090-1098.

208. GISSI-HF Investigators. Effect of $n-3$ polyunsaturated fatty acids in patients with chronic heart failure (the GISSI-HF trial): a randomised, double-blind, placebo-controlled trial. Lancet 2008;372:1223-1230. 
209. Goldberg RB. Impact of thiazolidenediones on serum lipoprotein levels. Curr Atheroscler Rep 2006;8:397-404.

210. Bolen S, Feldman L, Vassy J, et al. Systematic review: comparative effectiveness and safety of oral medications for type 2 diabetes mellitus. Ann Intern Med 2007;147:386-399.

211. Dormandy JA, Charbonnel B, Eckland DJ, et al.; PROactive Investigators. Secondary prevention of macrovascular events in patients with type 2 diabetes in the PROactive Study (PROspective pioglitAzone Clinical Trial in macroVascular Events): a randomised controlled trial. Lancet 2005;366:1279-1289.

212. Nissen SE, Nicholls SJ, Wolski K, et al.; PERISCOPE Investigators. Comparison of pioglitazone vs glimepiride on progression of coronary atherosclerosis in patients with type 2 diabetes: the PERISCOPE randomized controlled trial. JAMA 2008;299:1561-1573.

213. Barter P, Caulfield M, Eriksson M, et al.; ILLUMINATE Investigators. Effects of torcetrapib in patients at high risk for coronary events. New Eng J Med 2007;357:2109-2122.

214. Scheen AJ, Finer N, Hollander P, et al.; RIO-Diabetes Study Group. Efficacy and tolerability of rimonabant in overweight or obese patients with type 2 diabetes: a randomised controlled study. Lancet 2006;368:1660-1672.

215. Després JP, Golay A, Sjöström L, Rimonabant in Obesity-Lipids Study Group. Effects of rimonabant on metabolic risk factors in overweight patients with dyslipidemia. N Engl J Med 2005;353:2121-2134.

216. Hennes S, Robinson DM, Lyseng-Williamson KA. Rimonabant. Drugs 2006;66:2109-2119.

217. Nissen SE, Nicholls SJ, Wolski K, et al., STRADIVARIUS Investigators. Effect of rimonabant on progression of atherosclerosis in patients with abdominal obesity and coronary artery disease: the STRADIVARIUS randomized controlled trial. JAMA 2008;299:1547-1560.

218. Christensen R, Kristensen PK, Bartels EM, et al. Efficacy and safety of the weight-loss drug rimonabant: a meta-analysis of randomised trials. Lancet 2007;370:1706-1713.

219. Bantle JP, Wylie-Rosett J, Albright AL, et al. Nutrition recommendations and interventions for diabetes - 2006: a position statement of the American Diabetes Association. Diabetes Care 2006;29:2140-2155.

220. The Advance Collaborative Group. Intensive blood glucose control and vascular outcomes in patients with type 2 diabetes. N Engl J Med 2008;358:2560-2572.

221. ADVANCE Collaborative Group; Patel A, MacMahon S, Chalmers J, et al. Effects of a fixed combination of perindopril and indapamide on macrovascular and microvascular outcomes in patients with type 2 diabetes mellitus (the ADVANCE trial): a randomised controlled trial. Lancet 2007:370:829-840.

222. The Action to Control Cardiovascular Risk in Diabetes Study Group. Effects of intensive glucose lowering in type 2 diabetes. N Engl J Med 2008;358: 2545-2559.

223. Collins R, Armitage J, Parish S, et al.; Heart Protection Study Collaborative Group. MRC/BHF Heart Protection Study of cholesterol-lowering with simvastatin in 5963 people with diabetes: a randomised placebo-controlled trial. Lancet 2003;361:2005-2016.

224. Tonelli M, Isles C, Craven T, et al. Effect of pravastatin on rate of kidney function loss in people with or at risk for coronary disease. Circulation 2005;112:171-178.

225. Sandhu S, Wiebe N, Fried LF, Tonelli M. Statins for improving renal outcomes: a meta-analysis. J Am Soc Nephrol 2006;17:2006-2016.
226. Douglas K, O'Malley PG, Jackson JL. Meta-analysis: the effect of statins on albuminuria. Ann Intern Med 2006;145:117-124.

227. Stepherd J, Kastelein JJ, Bittner V, et al.; Treating to New Targets Investigators. Effect of intensive lipid lowering with atorvastatin on renal function in patients with coronary heart disease: the Treating to New Targets (TNT) study. Clin J Am Soc Nephrol 2007;2:1131-1139.

228. Smulders YM, Rakic M, Stehouwer CD, Weijers JN, Slaats EH, Silberbusch J. Determinants of progression of microalbuminuria in patients with NIDDM: a prospective study. Diabetes Care 1997;20:999-1005.

229. Dodson PM. Medical treatment for diabetic retinopathy: do the FIELD microvascular study results support a role for lipid lowering? Practical Diabetes 2008;25:76-79.

230. Gupta A, Gupta V, Thapar S, Bhansali A. Lipid-lowering drug atorvastatin as an adjunct in the management of diabetic macular edema. Am J Ophthalmol 2004;137:675-682.

231. Keech AC, Mitchell P, Summanen PA, et al.; FIELD Study Investigators. Effect of fenofibrate on the need for laser treatment for diabetic retinopathy (FIELD study): a randomised controlled trial. Lancet 2007;370: 1687-1697.

232. Simó R, Hernández C. Fenofibrate for diabetic retinopathy. Lancet 2007; 370:1667-1668.

233. Diabetes Prevention Program Research Group. The prevalence of retinopathy in impaired glucose tolerance and recent-onset diabetes in the Diabetes Prevention Program. Diabet Med 2007;24:137-144.

234. Chew EY, Ambrosius WT, Howard LT, et al.; ACCORD Study Group. Rationale, design and methods of the Action to Control Cardiovascular Risk in Diabetes Eye Study (ACCORD-EYE). Am J Cardiol 2007;99(suppl 12A): $103 \mathrm{i}-111 \mathrm{i}$.

235. Cameron N, Cotter M, Inkster M, Nangle M. Looking to the future: diabetic neuropathy and effects of rosuvastatin on neuromuscular function. Diabetes Res Clin Pract 2003;61(suppl 1):S35-S39.

236. Gulcan E, Gulcan A, Erbilen E, Toker S. Statins may be useful in diabetic foot ulceration treatment and prevention. Med Hypotheses 2007;69: 1313-1315.

237. Coste TC, Gerbi A, Vague P, et al. Neuroprotective effect of docosahexaenoic acid-enriched phospholipids in experimental diabetic neuropathy. Diabetes 2003;52:2578-2585.

238. Gerbi A, Maixent J-M, Ansaldi J-L, et al. Fish oil supplementation prevents diabetes-induced nerve conduction velocity and neuroanatomical changes in rats. J Nutr 1999;129:207-213.

239. Davis TM, Yeap BB, Davis WA, Bruce DG. Lipid-lowering therapy and peripheral sensory neuropathy in type 2 diabetes. The Fremantle Diabetes Study. Diabetologia 2008;51:562-566.

240. Okuda Y, Mizutani M, Ogawa M, et al. Long-term effects of eicosapentaenoic acid on diabetic peripheral neuropathy and serum lipids in patients with type II diabetes mellitus. J Diabetes Complications 1996;10: 280-287.

241. Burgess D, Hunt D, Li LP, et al.; on behalf of the FIELD Investigators. Effects of fenofibrate on silent myocardial infarction, hospitalization for acute coronary syndromes and amputation in type 2 diabetes. The Fenofibrate Intervention and Event Lowering in Diabetes (FIELD) study. Circulation 2007;116:II 838 (abstract). 